QL

606.56

J3 039

PEPT.

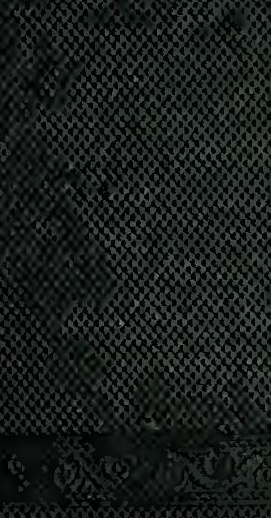

3. 11 


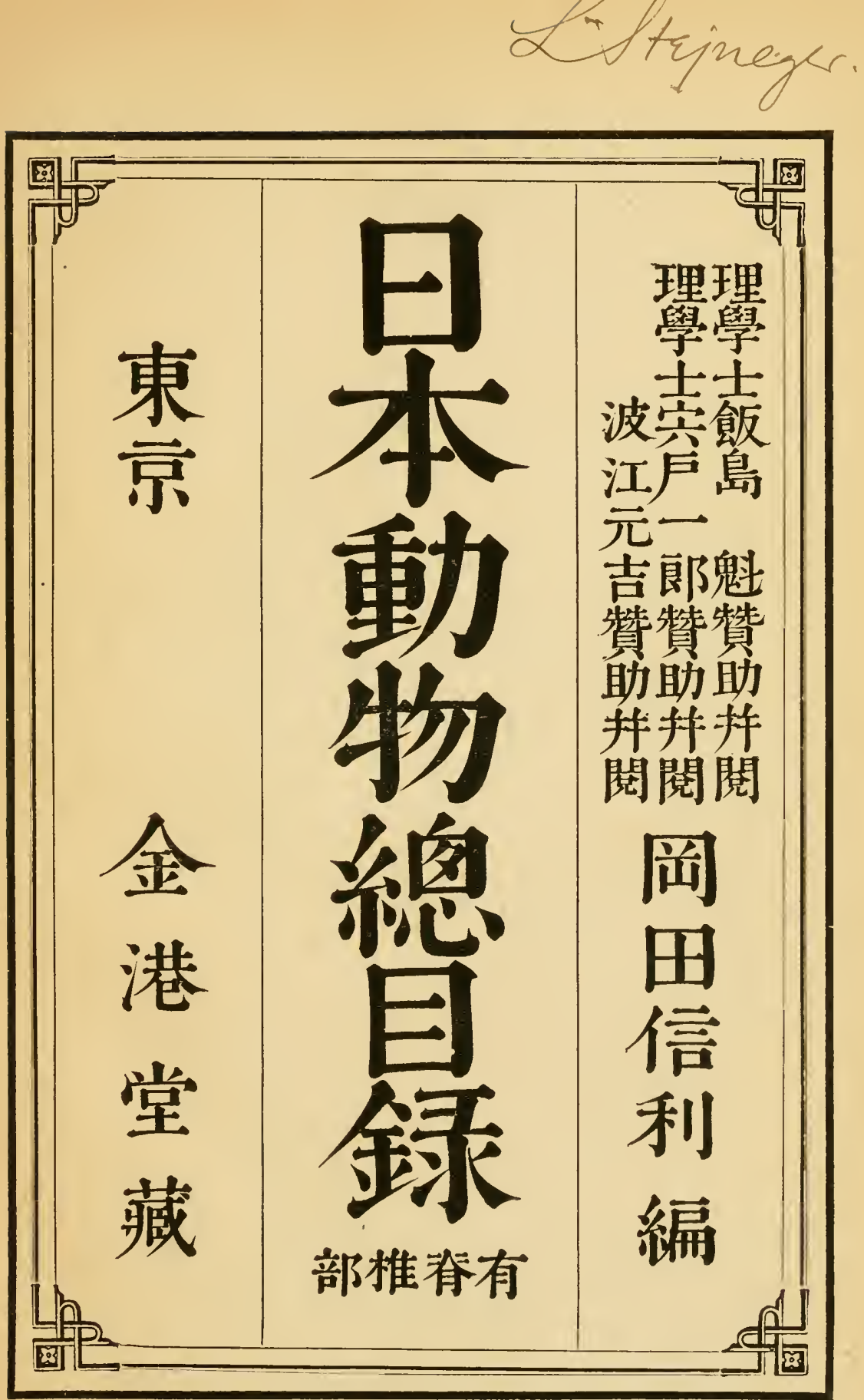

QL

606.56

J3039

Rept.

\title{
CATALOGUE
}

\author{
OF
}

\section{VERTEBRATED ANIMALS}

\author{
OF \\ $\mathrm{J} A \mathrm{P}$ A N/
}

$\mathrm{BY}$

S. OKADA.

TOK Y $\overline{\mathrm{O}}, \mathrm{J}$ A PAN :

KIIKのDO.

2551 (1891.) 



\section{$\left(\begin{array}{c}\text { Silhsonian Institutio } \\ \text { STEJNEGER } \\ \text { COLLECTION } \\ \text { National Museum }\end{array}\right)$}

日岡求余之基小而

本田余知禆用少弁明

有信序君谷之也一治

脊利余之於有君言草

椎君素志我資之卯

動製謟于邦於見入

物日於此人我荅梅

日本動學不邦在 日

錄有物有霄海茲

序脊學年雼隋歟

椎者於其之聊

動又泫理物村

物何盖之產度

目言此妙决其

錄然學而非意

天

台

道

士

識 

预學クキルルク二恶ハン 友實涉余多世本 斗實哉 岡物 獵先 $\neq=$ 邦一卒二盖 田 $=y=$ 示所》本 信就得乞思 メ產テ邦此

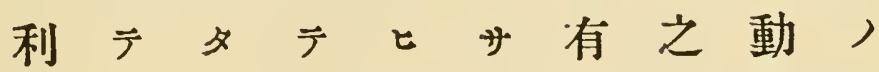
君之几之君 八 $\neq$ 所 $\neq=$ 二 椎世學 キ 多調, 通勸 フ動二發完 年查手覽告 物 公達全 本シ記シス以目 $=$ オ 邦且八書几テ錄七雼几 動 $ッ$ 積中 物 傍 デ収速タ新 $ン=$ 錄 ノラ數錄ニり著ン豈八 研和册 ス之 $⿻$ 入 究漢, 几舟而》ス之來 二歐書所上 $y$ 將 從米 $\neq$ 世梓今 $=$ 賀邦 事古成 = シ 其會 七 $=$ シ今ス裨以同編シザ於 親, 二盆 シ書至 ス廣此ノル可未 
ダキタべノク

其舉 几キ動信明 類 グキャ物沙治

* $几$ 以 $\neq$ 學 $\overline{\text { 四 }}$

見, テ知二疑年

ズミ䨋ラ從八六

而ナメシ事ザ月

y $ラ=x$ ス 理

書ズ探タ几所科

中亦集り者ナ學

載併者誠 キ リ授

錄七 $7=$ 裨

ス $\bar{y}$ 此䀂

理

學

几各其, ス

$\pm$

所地種如 几

唯分

二布 如ナ

分, 何几上

ド

ク

r

ル

類一) × ᄀ

及斑地以八

翎

䛲

ビ $キ=テ$ 余

名記荣此,

鬼斗

稱シム書固 
動 可 ゙究邦十シ以セ 物

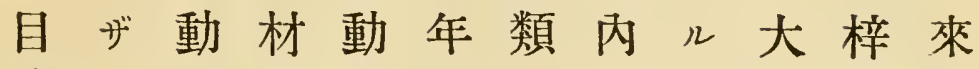
錄儿物料物波, 外モ三盡媓 , 力 動如種供目元, 八者夕十 物 シ類 ス 錄吉噙モ縱 學而及几八氏矢, 令㿽 者シビコ今呚ナキ之シ以星. $=$ テ名卜日育 必其稱, 二博ン擧知几容 要有 $*$ 二至物全 $シ$ 八易經 ナ用確點 几館書且 $\mathrm{s}=$ 今 ルナ定 八ルス ア ア 猶所几リ未目名邦登头得卜 木以コ然名錄, 產載俟心゙ナ 書 7 ト 完中示, ス カ 籍述ト二全動ス動几ズ 目フ第遺ナ物如物 7 然 ゙其 錄レ二憾ル, クナ得ル之間 ノバ ニトモ部列 ルザ 二 = 學 圖第動謂, $\neq$ 品モn全加術 書一物ファ著目全, 書つ, 舘二分心゙ 7 七錄館憾入儿進 二研布キズシナニア數二步 欠究上八明八儿貯り年其モ クス研本治蓋 
著ル照フ氏次テ

シ者 $ラ$ 是 $=$ 卷

ク, シ實謝㳄首明

新一廣二七体三治

二般ク今ザ動弁廿

本二諸日几物

邦感書, 可昆

年

産ス

動 ル參乏ザ類

七

物 所考二几等

月

目ナ之應所,

錄りテスナ目

キ $三$ 日 $几$ リ錄

發二本, 望

行今産モラ著

又回有, ク八

几適脊二八 サ

, 岡椎 $三$ 全

理

學

博

$\pm$

必田動テ氏

要信物我,

箕

八利目輩佾 聊

動 氏 錄動 木 所

作

物多 多物業見

學年著學

キ人, 八者續陳

佳

攻經 ス, キ シ

究驗二梁 $テ$

ス二遇》漸以 
予 キ動ナ問是卜佾鳥吕臆書 動記物シフ書云木部喿撰中 物シ二置我フ杜八間 例學或關 $\neq$ 邦 $=$ 撰 二八スタ 言志未ルル栖ラ漏吕突ズモ シ夕記 キ 其事 今 皮物 校 リ 見定 一見聞删 動 ス ス 補 物 ト ル

于 雖 每 日 獲 $E=$ 本 几凡筆有 每 ソ記脊 二我三椎 彼 邦以動 此 $=\vec{\tau}$ 物 , 栖坐目 書息右 錄

$=\pi, \mathrm{r}$ 徵 ル 備 題 三 有忘 學脊 錄世 名椎 息不等
ス 唯尠
几 余カ

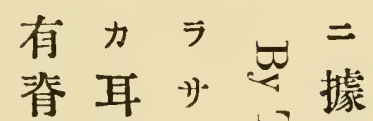
椎目ル: 動, 乞立間 タ 物及三匹鄙曲 ノフ同罢モ 名所學要 $\neq$, 稱 $キ$, 加 及記君蓄へ 七至增 1) 產、幸補 物 地, = F三是 名 綱後正羅進省阄 シ, 給 夕鮕 新 稱 F 下 シ 末 》生@皆 


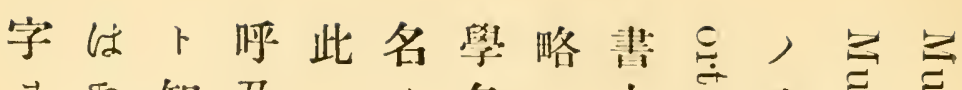

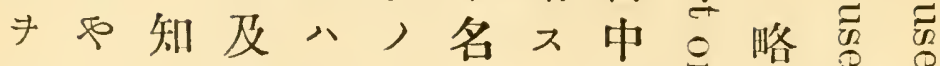
記8几産何ミ, 產志导志志 シりへ地ナキ下地 。 以岡 $シ * ⿻$ 揭二 テ田例載彼ヶ一 之ノをセ八テ々 テ如 八业何後其 分 $\Sigma \varepsilon n=$ 㪀出 ツ义まモナキ典 例括へ, リ俟 キ 之弧ひ尠「ツ明 八才后 シ今記 己施めト揅 ス

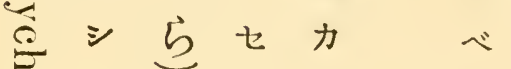
其广 ス二、キ

导中如其考筈

手 三外定

名何又國 ス

苛々敟, 儿

○名悲二

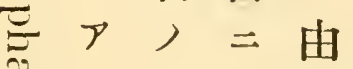

こルミ記ナ

吉八揭述シ

其ヶ 姑

さ一我りク

な名稱厅學

) 地只, , 下 $\stackrel{0}{\circ}$ 略略

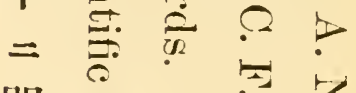

間官少少 咯 告

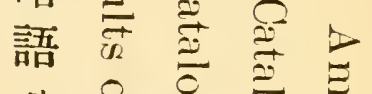

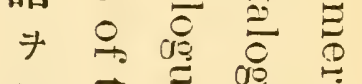

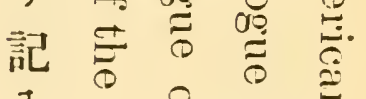

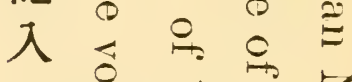

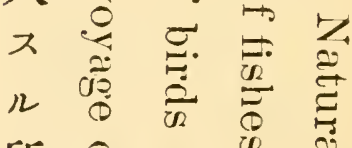

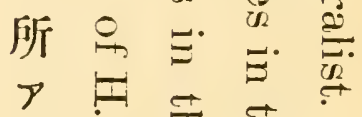
リ $=\overrightarrow{0}$,

1) 例 8 \& 略 今 之 $\varrho \overline{\overline{8}} \overline{\bar{\theta}}$ 煩 =

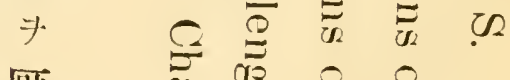

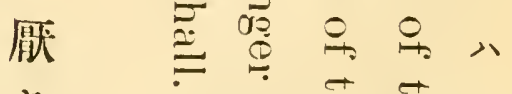
t

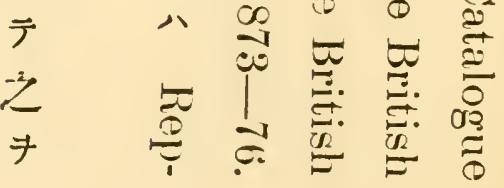


啓此全閱厚理居

書編替誼科几明

本選 $\neq$ 助 7 大 7 治

草輯第, 謝學 $\neq$ 廿

綱, 二勞 $九$ 敎併四

目後高罂授七年

啓理等執》理記四

蒙科中 5 此學

E) 大學几書博茲

宅略學校爲脱士二 鳥 教 呚 $\nsim$ 稿箕 感

便授授二世作謝

言八饭理一”住,

鳥嶋學屡公吉意

名魁士, 二先

品便先突完 2 生表

覽生戶全几多ス阙

人八一キ二年

略禽郎十至循

田

它部君スり誘 知 7 八因为,

波魚テル功

信

こ 江部記モ筫

严シ元 $*$ シ =

利

, 吉想以他多石

略. 君二テナキ

本 八校其 $シ=$ 

日皇水鳥飼觀帝 鯨鯨鯨 畫 加 本和族名籠文國志史及圖賀 魚魚志便鳥禽博稿海西産 譜譜覽譜物豚遊物

引

用

書

目
舘

所

藏

各談志

種

禽圖

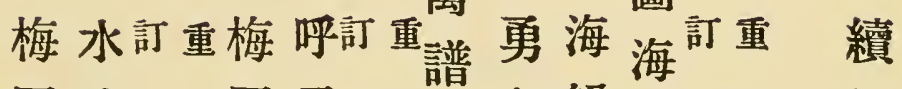
園族本園子本正堀鯂觯本筑

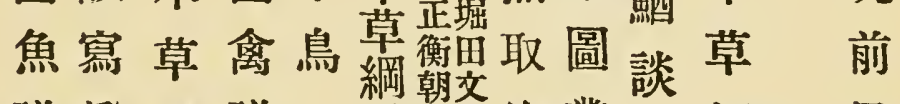
譜畺綱譜 具臣庫繪叢綱風

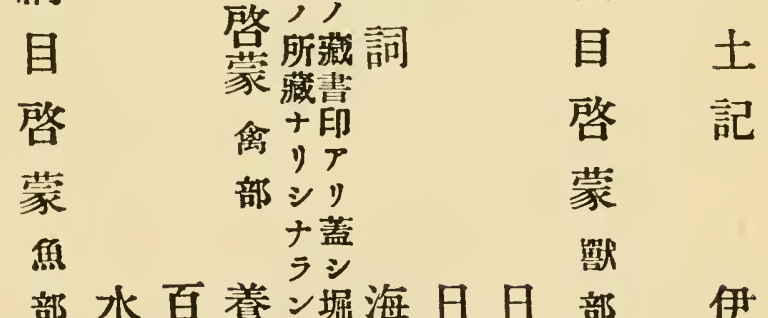

湖王部水百養淈海日日部伊 魚釷谷金田 魚餘＼cjkstart谷千禽 食本本豆 考魚氏鳥物獻產捕 圖禽語志鯨鯨 志 彙譜 稿鯢彙$$
\text { 之考 }
$$$$
\text { 圖 }
$$ 
両小南八南琉知天石水水郄島 國笠嶋文沉球床墟狩產產㕕根 本原雜筆錄國日日日調會博縣 草島志記志誌誌誌查報物 敎 紀 略

䖥告舘圭

事 察列 會 報品 雜

阿北伊八日束納十 告目誌 淡海豆文本蝦沙勝 產道七志產夷布日 錄 動 物 志志島物日日誌 明志誌誌 之 部 細 記

津奥信七中西久後動北博 嶋邪濃嶋山蝦摺方物水物

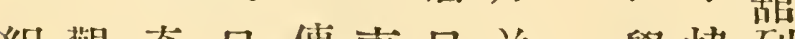
紀觀 奇日傳㚕日羊學協列 事跡勝記信日誌蹄雜會品 聞錄錄誌日誌報錄 老 誌 告 天 志 辇 


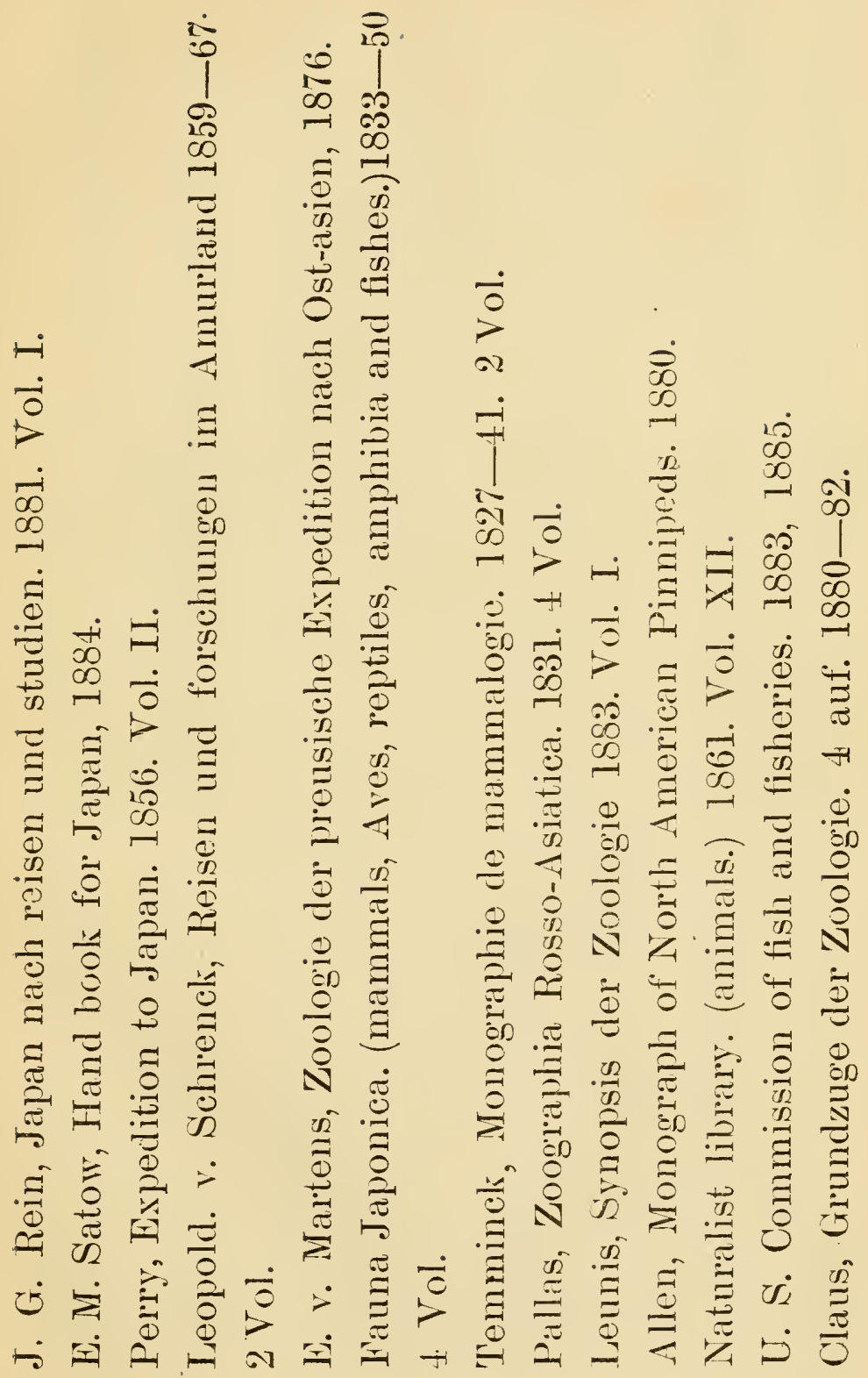




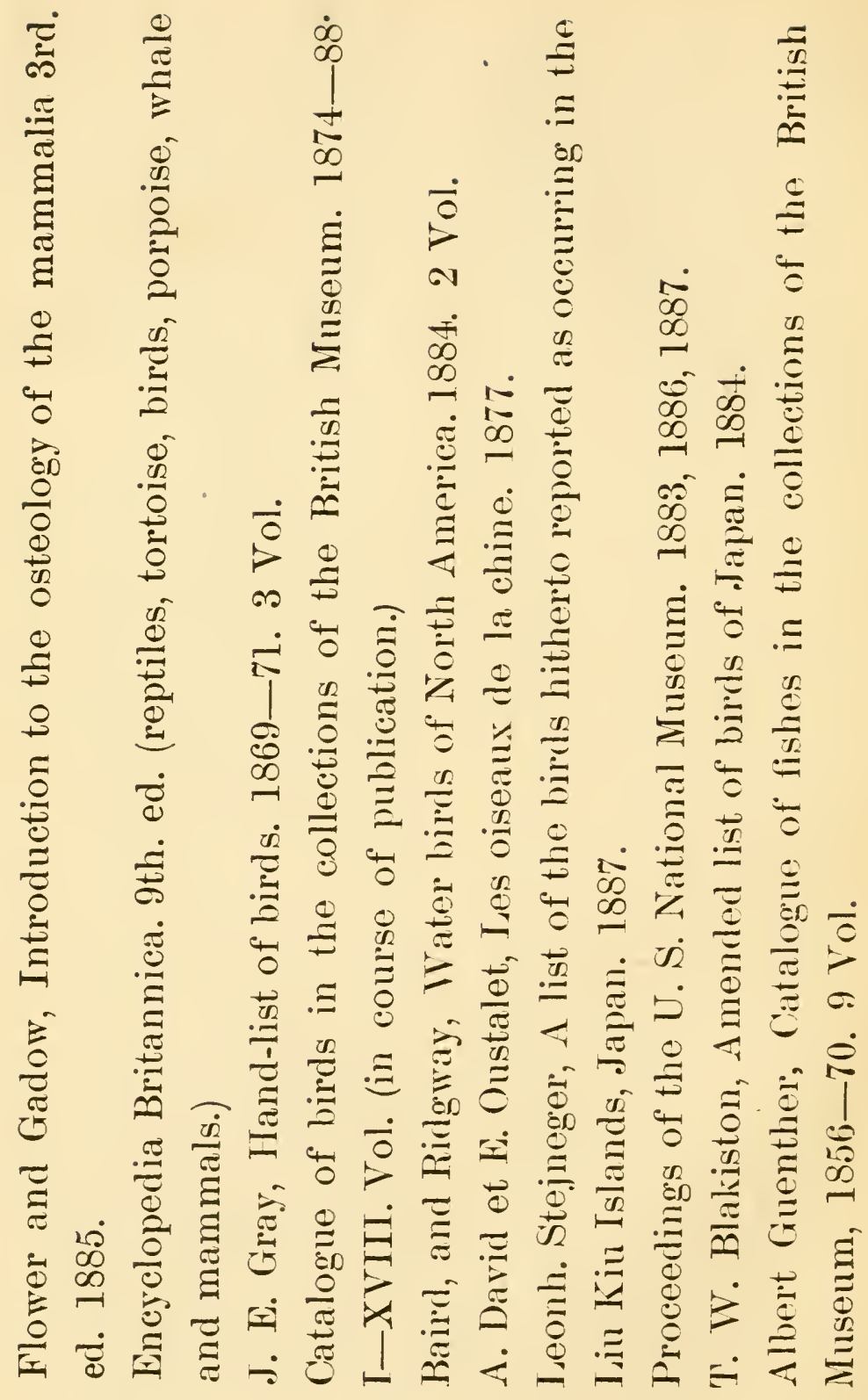




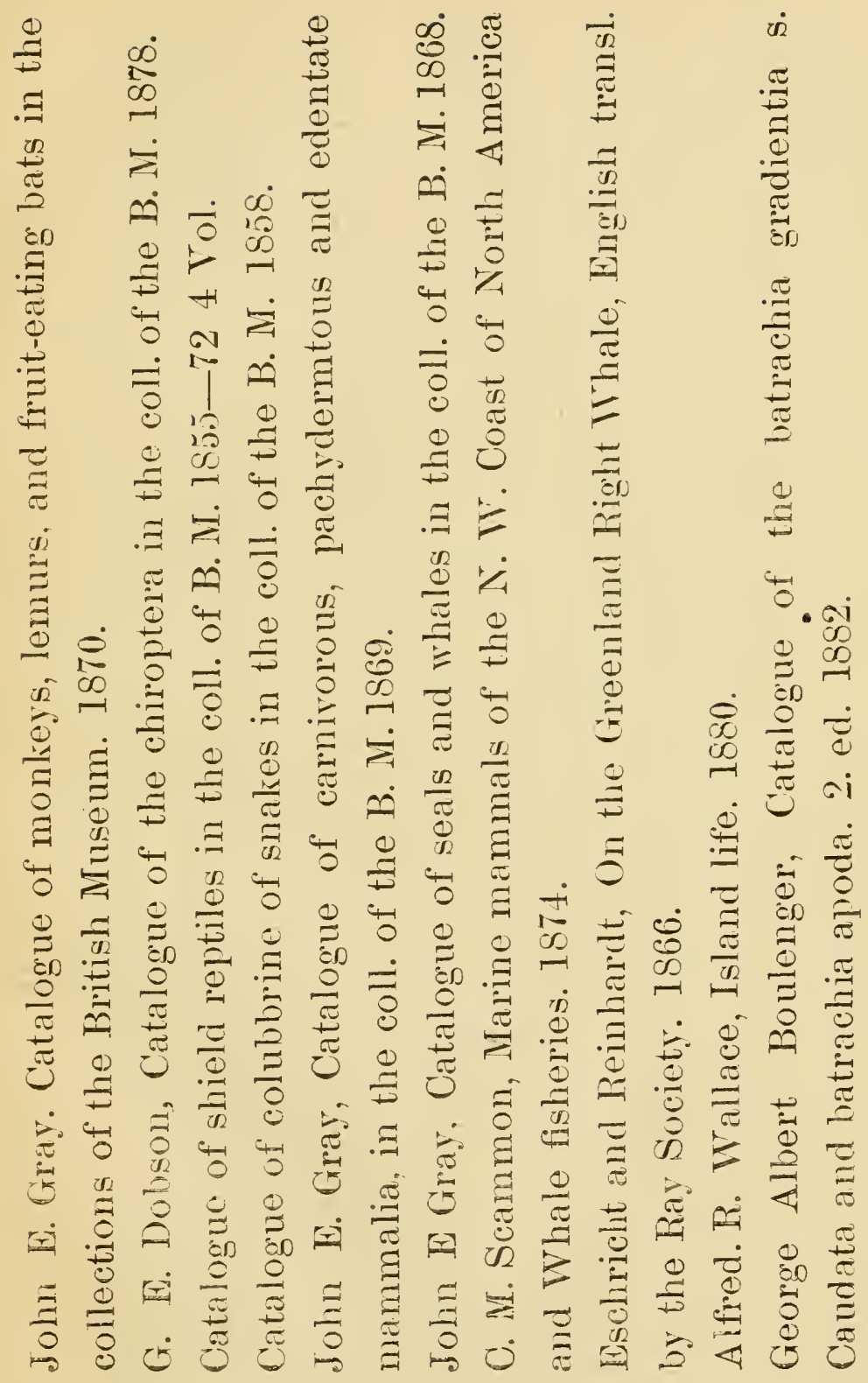




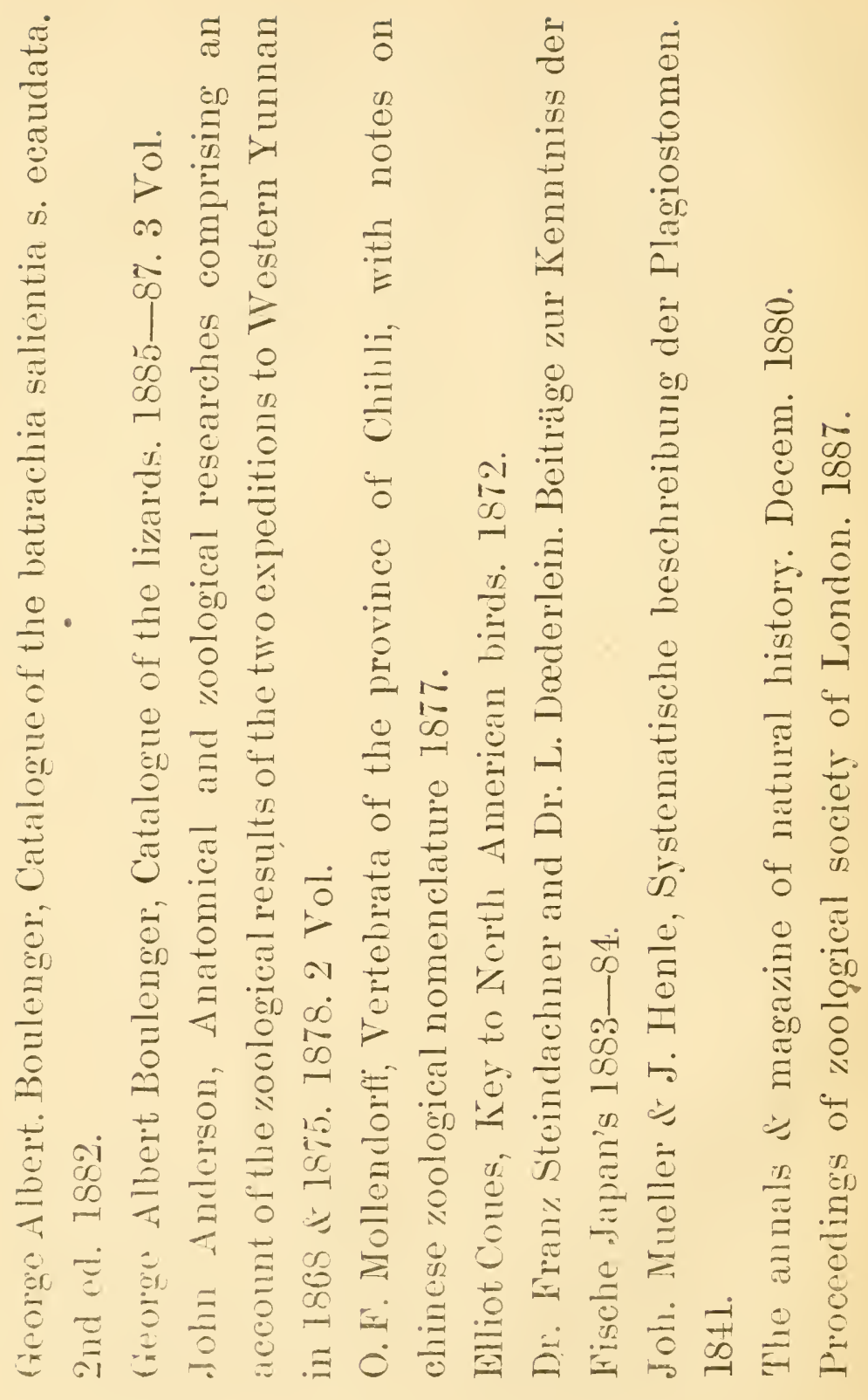




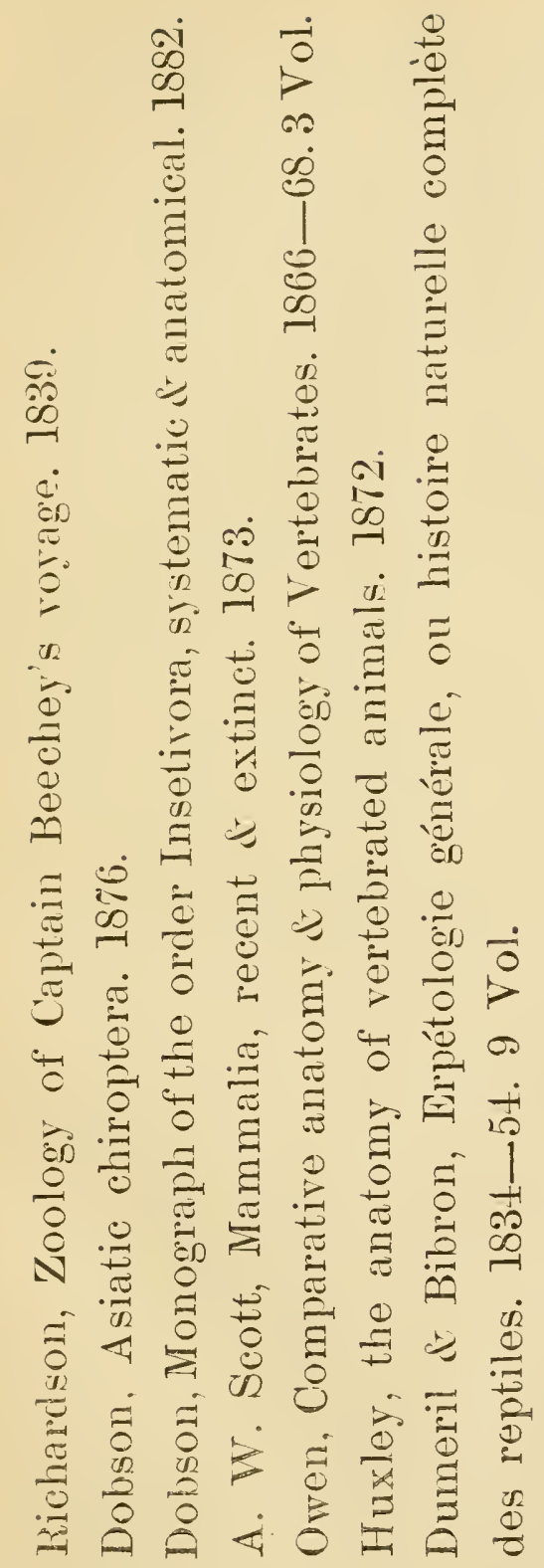





\section{SUBKINGDOM VERTEBRATA.}

\section{CLASS PISCES.}

ORDER LEPTOCARIIJ.

Amphioxus, Yarrel.

豊後位驾關 筑前志賀昜

$$
\begin{aligned}
& \text { lanceolatus, Turrel. } \\
& \text { ナメクジゥэ}
\end{aligned}
$$

SUBCLASS CYCLOSTOMATA.

Family Mryrimider.

Myxine, $L$.

anstralis. . Tenyns.

江ノ島沖

Bdellostoma, Joh. Mïll.

安房

cirrhatum, Sihley.

メクラウナギ

Fannily I'rtrommsontider.

Petromyzon, trt.

石狩川(石狩) 越前端非起淩高田

fluviatilis, $L$.

ヤッメウナギ

branchialis, $L$.

スナヤッメ

東京周防山口尾張濑戶咑遠江清水川

\section{SUBCLASS PALAEICHTHYES.}

ORDER CHONDROPTERYGII.

Suborider Plagrostonata

A. Selachoidei.

Finnily r'archariider.

Carcharias, $\ulcorner u$.

安房相摸肥前

japonicus, Sichleg. 


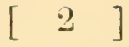

laticamins, . $/$. \& $H$.

昍前

acutus, Riiijl.

肥 前

$$
\text { walbeenii. Iilorli. }
$$

此 前

Galeocerdo, il. $/ \%$.

肥前

Zygaena, c'uv.

mallens, liisso.

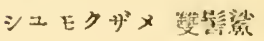

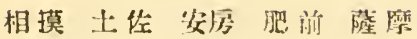

Galeus, ' ' 12 .

jayonicus, $1 \%$, $1 /$.

肥前

Mustellus, "uc.

maนa\%o, lilreli.

ホシザメ(シャザメ) 鮧奥

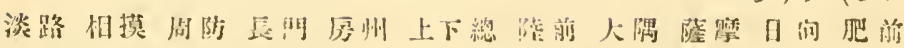

Trias, Mïll. il Itente.

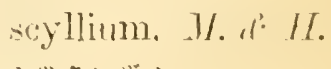$$
\text { カッタヒザメ }
$$

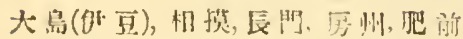

Finnil!y lamnida.

Lamna, ('

glatica. $1 /$. , $1 /$.

安汸肥部 


\section{[ 3 ]}

comubica, Flem.

肥前

$$
\text { Family Notidanide. }
$$

Notidanus, Cuv.

相摸

$$
\begin{aligned}
& \text { indicus, . } \\
& \text { アブラ师メ }
\end{aligned}
$$

Chlamydoselachus, Garm.

椙摸 anguinens, Garm.

$$
\text { カグラザメ }
$$

\section{Fumily signllider.}

Scyllium, TI. $H$.

$$
\begin{aligned}
& \text { bürgeri, } . / . \text { a } H . \\
& \text { カヌカザメ }
\end{aligned}
$$

安原, 㥵摸, 肥前

Chiloscyllium, $M$. $H$.

indicum, \&m.

相擳

$$
\begin{aligned}
& \text { indicum, (t).. ru. } \\
& \text { plagiosa. } \\
& \text { indicum, Gm.. rur. } \\
& \text { margaritifera. }
\end{aligned}
$$

Crossorhinus, $1 / H$.

相摸 把前

$$
\begin{aligned}
& \text { barbatus, M. \& } / \ell \text {. } \\
& \text { *リノトブカ }
\end{aligned}
$$

Fumily Cestraiontida.

Cestracion, cul.

$$
\begin{aligned}
& \text { philippi, Cuc. }
\end{aligned}
$$

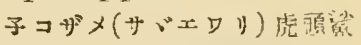

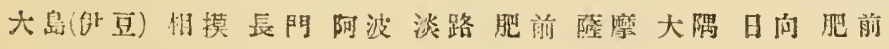




\section{[ $4 \begin{array}{ll}4 & ]\end{array}$ \\ Family spinacide.}

Acanthias, Risso,

駿河肥前

$$
\begin{aligned}
& \text { vilgario, liiso. } \\
& \text { ッグォ }
\end{aligned}
$$

Centrophorus, II. d $H$.

squamulosus. Gthr.

㐭）品沖

foliacens, fillir.

江, 息沖

Spinax, (ur.

相摸安房

grautulosus. Githr.

カラフ・将

Scymnus, Cur.

駿河

lichi:e, ('ur.

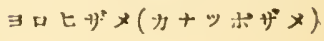

\section{Fimily Rilimider.}

Rnina, Klein.

squatiua, T.

カスザメ菙演

安房薩摩大溜日们肥新

Fiomily Pristioghturide.

Pristiophorus, 1\%, * $H$.

相摸肥前数点

jationicus, (ithr.

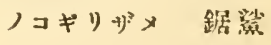

B. Batuidei.

l'amily, Lihimobutiden.

Rhinchobatus, $1 \%$. \& 11 .

djeddensis. Torsti-

相摸肥解

$$
\text { トンガリ }
$$




\section{[ 5 5 ]}

Rhinobatus, $M . \& H$.

安房 肥前

schlegelii, $I I$. \& $H$.

サカタザメ(スキノサキ)整項魚

columir, 7 . $I$.

肥 前

Family 'Torpedinide.

Astrape, $1 \%, \%$.

治河肥 前?

dipterygia, Bl. Solm. シビレエヒ

Narcine, Henle.

timlei, 13. Srhn.

\section{Family Raijide.}

Raja, Art.

相摸肥前

$$
\begin{aligned}
& \text { kenojei, } 1 \text {. } H \text {. } \\
& \text { ガンギェヒ（カスべ）刺蟥 } \\
& \text { isotrachys, Githr. }
\end{aligned}
$$

South of Japan (Chall.)

Platyrhina, $M$. $H$.

sinensis, $\lambda . d \%$.

ウチハスヒ(シチハザメ)

安房薩㯲大隅日向肥前

$$
\text { Fumily 'Trygonide. }
$$

Trygon, Idenson.

pastinaca, $L$.

相摸淡路長門肥前陸前薩摩大隅日向

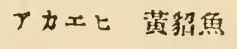




\section{gerrardi, froly.}

贬前:

kuhlii, ./. \& $H$.

犱新

$$
\text { zugei, } 1 \% \text {, } \Pi \text {. }
$$

肥前

Pteroplatea, $M$. \&. $H$.

\section{安原肥前}

himundo, Ione.

ヨコサ(ッバクラメヒ)牛焦

Urolophus, $M$. . $H$.

cruciatus, Immeril.

把胡

\section{Family Myliobatida.}

Myliobatis, ('ur.

筑前肥前

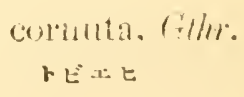

nienhotii. IH. Silln.

Aetobatis, $M$. \& $I I$.

marinati. M. . $H$.

肥 前

Dicerobatis, Iilcinzille.

jitponica, $M$. a $H$.

把前

安原對㷂

$$
\begin{aligned}
& \text { giornae; Láple } \\
& \text { イトマ平比 }
\end{aligned}
$$


Suborder Holocephlalu.

Family Clivimeride.

Chimæra, $L$.

monstrosa, $I$.

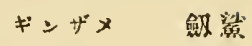

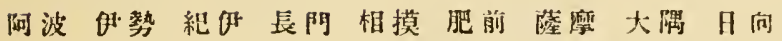

$$
\begin{aligned}
& \text { ORder GaNOIDEI. } \\
& \text { Suborder Chosdrostei. } \\
& \text { Family Tijumserille. }
\end{aligned}
$$

Acipenser, $L$.

石狩國石狩川

$$
\begin{aligned}
& \text { sp. } \\
& \text { テウジメ鰂息 }
\end{aligned}
$$

\section{SUBCLASS TELEOSTEI. \\ ORDER PLECTOGNATHI. \\ Family rymmodontes.}

Orthagoriscus, Bleek.

常陸

Diodon. $I$.

mola, $l$.

マンボウ（ウキ、）跳車魚

加賀 相摸 越中越後

Chilomycterus, Cithr.

相摸 紀据

muculatus, Gthr.

ハリセンボン 奥虎

Tetrodon, $I$.

三崎（知摸）

tigrinus, Cmr.

ヒシフダ

lievigatus, $L$.

シラタフジ

Iunaris. Blecli.

ギンフダ

相摸薩摩肥前大隅 日向 
相摸把解

相摸肥前

安居

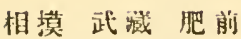

帽摸发原肥剈

相摸䗆原把前

相误茹原

\section{露筑话}

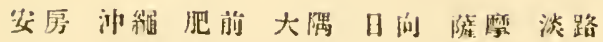

相摸

scelatus, forst.

サバフグ

rubripes, Silley.

トラフグ

rubripes, Schley. vir.

xumthopterus.

シマフォ（スシング）

vermicularis, Sillleg.

マフグ（コモンフが）

stictonotus, Schleg.

カノコフダ( ゴマフグ)

lardalis, Sihley.

ナゴヤフタ

chrysops, Milgel.

$\curlyvee カ フ タ$

cutameus, Githr.

ヨリトフグ(タカトウフグ)

1)orphyreus, Sithleg. シホサイファ゙ 嬩解

stellatus, Bleck.

テマリフジ

firmamentum, Sichleg. モンガラフグ

把的限摩 
相摸肥前隡磨大隅日向

相摸肥前

相摸肥前薩摩

Triodon, C'uv.

安房 rivulatus, Schleg.

キンチヤクフシ

grammatocephalus,

ヨコフグ Schlleg.

oblongus, Bleck.

カラクサフグ

bursarius, Cun.

$$
\text { ウチハフグ }
$$

Fumily Sclerodermi.

Triacanthus, Cur.

安原肥前

brevirostris, Silleg.

ッノハフ

Triacanthodes, Bleek.

anomalus, Blech.

\section{Monacanthus, Cuv.}

安屠周防淡路

相摸

setifer. Benn.

カワハギ

monoceros, Osb.

ウマッ゙ラカワハギ

septentrionalis, Gthr.

modestus. (ithr.

oblongus, schleg.

把前 
肥前

nasicormis, Sille'\%.

肥 前

Balistes, $C^{\prime} u r$.

紲泋 小笠原岛

maculat us, (irce)!.

モンガカカハギ

Ostracion, $L$.

相摸大㵻日向㓌摩

cubicus. $/$.

ハコフダ

coruntus, $l$.

コンガッフダ海牛

相摸

diaphauus, likerli.

ス、゙メフグ

肥 前

安展贬首

roncitenalls. Iilidi.

Aracana, liray.

相摸

iculeati. HIoutl.

イトマキフ

\section{ORDER LOPHOBRANCHII.}

Fomily Symquethider.

Hippocampus, Ieach.

肥前

coronatus. Sillerg.

ッノウーウマ

antiquarmom, leceh.

汁前

肥前

longirostris, Schle!!.

クサナギ 
guttulatus, Cur.

mohnitei, Blecti.

hystrix. Kenup.

Acentronuma, Kéup.

相摸

gracillimus. Kurup.

ウミウマ 海馬

Syngnathus, $1 v t$.

安房

schlegclii. Kin!y.

ナウジウキ

intermedins, Kuny.

srayi, Kunp.

長㥓

serratus. Selleg.

相摸越前致贺灣，肥前

\section{ORDER PHYSOSTOMI.}

Muræna, L.

安房 相摸

nubila, Rivcharels.

ッッポ 鲜魚

I'trdalis, Schleg.

ベビゥッポ

安居紀作肥前

reticularis. Bleck.

肥的 


\section{Ophichthys.}

cephalozona, Blect.

肥站

hepatica, Riiiply.

肥前

reevisii, Richurds.

肥前

Moringua, Crray.

javanica. Ku(un).

肥前

Ophichthys, lithr.

mrolophus, Silley.

ทミへビ

肥 前

肥前

$$
\begin{gathered}
\text { serpens, } I . \\
\text { ギシバリ }
\end{gathered}
$$

rostellatus, Richurels.

$$
\text { ダイナンシミへレ゙ }
$$

安居肥前

Nethastoma, Raj.

jarviceps, Cithe.

South of Yedo. (Chill.)

Murænœsox, II.' ('ell.

cinerens, Forsli.

八王 海䱻解

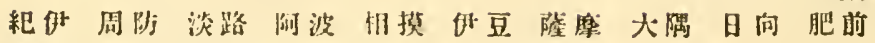
Myrus, Laup.

uropterus, Siluley.

肥前 
Congromuræna, Küup.

周防東京長門肥前

$$
\begin{aligned}
& \text { anago, Shlley. } \\
& \text { T+コ๋ }
\end{aligned}
$$

megast mata, (cthr).

myriastar, Breroort.

函舘 㝵京灣

Conger, Cथr.

marginatus. I".

肥首解

昍前

vulgaris, C'ue.

マアナゴ

Anguilla, $C u v$.

Jonstoniensis, $I$.

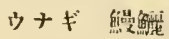

東京阿波淡路䧓防日向豊後

$$
\begin{aligned}
& \text { marnorata, Quoy. d. } \\
& \text { カニクラヒウンギ Gaim. }
\end{aligned}
$$

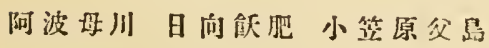

Synaphobranchus, Johns.

innatus, Gthr.

相摸洋

bathylius, Gtlur.

South of Yedo (Chall.)

brevidorsalis, Gthr:

相摸洋 


\section{[ 14 ] \\ Femily Herlosentrider.}

Halosaurus, tiolens.

affinis, cithr.

South of Japan (tholl.)

Family lintlytflerissidee.

Bathythrissa, riunth.

$$
\text { dorsalis, Gthe. }
$$

相摸溯

Finimily Voiturantlio.

Notacanthus, lioch.

rissuanus, $F$, di:

相摸洋

\section{Fiemily chuswider.}

Etrumeus, 1ileel:

$$
\begin{aligned}
& \text { miclopus litrlio } \\
& \text { シルメイワシ }
\end{aligned}
$$

淡路肥前

Elops, 1.

samils, $l$.

カウライイワシ

肥前

Albura, Cirome.

comorlyonchne, lils sidne.

Pellona, $1.1 \%$

䤚前

elongatil. bimnett.

むおコノシッ 
Clupea, . 1 t:

常陸 北海道

備後事京灣

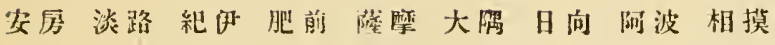

$$
\begin{aligned}
& \text { haxengus, } L \text {. } \\
& \text { ニシン (カド) 靑魚 }
\end{aligned}
$$

zumasi, Bleel.

サッパ(ッナシ)

melawosticta, Schley.

イワシ 䠄魚

sagax, Jen?nts.

Chatoessus, $111 \%$

1)nuctatus. Sihley.

コノシロ䱕魚

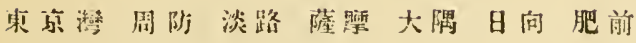
Spratelloides, Bleeh:

$$
\begin{aligned}
& \text { aracilis. Schleg. } \\
& \text { キビナゴ }
\end{aligned}
$$

把前薩摩大隅日台

Coilia, (ir)!y.

in 後 II!

$$
\text { nis:- schleg. }
$$$$
\text { ×ッ 筑魚 }
$$

Engraulis, C.. 1 .

$$
\begin{aligned}
& \text { japonicus, Houtt. } \\
& \text { 七ミコ }
\end{aligned}
$$

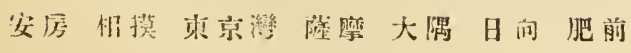

\section{Finmily Gonorlepnehider.}

Gonorhynchus, rironov.

相挩浥前 


\section{Fumily Sadmonider.}

Salanx, C'ux.

microdon, Blecti.

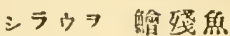

伊勢 偖前周防 筑前陸前

Osmerus, $A v t$.

epereamus. Laciep.

$$
\text { キウリウ }
$$

北海道

Hypomesus, riill.

北海道

olilus. Pall.

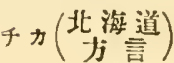

Onchorhynchus, Suckley.

perri, Hilyd.

マフ、留魚

越中加賀越後信潧

haberi. Hilgel.

サケ

利根川北海道詣川估濃川陸前

Si).

ベニマス

エトロフ虫

Plecoglossus, Scluey.

altivelis. Schley.

$$
\text { アニ 需魯 }
$$

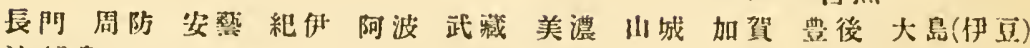
沪維島

Salmo, Art.

pluvius. Hilyd.

下野飛彈 信渋 武裁

$$
\text { イワナ }
$$

leneonomis, Pull.

ナメ マ

北游檤 
下野北海道

macrostoma, Gthr.

ヤマ^嘉魚

blakistoni, Hilgd.

イトウキ(チライプ方言 $)$

北海括

Family stornopitychide.

Sternoptyx, Her'in.

diaphana, Herill.

South of Yedo. (chall.)

Gonostoma, Rafin.

gracile, Gthr.

South of Japan. ('luall.)

microdon, Gthi.

('oast of Japan, South of Japan, Solith of Yedo.

Chauliodus, $13 \% .5 \mathrm{chn}$.

solanii, Bl. Schn.

Sonth of Japan

Fimmil!! Stomiatider.

\section{Photonectes.}

allipinnis, Död $\%$

Fimily Siomliesoride.

Exocoetus, $A v t$.

肥前

agoo. Schleg.

トビゥキ交䱊愿 
döderleinii, Strind.

\section{三宅島}

Scombresox, Lace'p.

大易( 伊豆)伊豆安原紀湖

Hemirhamphus, ' 'u'.

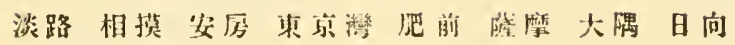
Belone, Cur.

東京㩐 肥前

安屏肥前

Fundulus, Lacép.

\section{Fiemily C'ynrinodontide.}

東京其他隨所

\section{Haplochilus, lithi.}

latipes, Schley.

肥前

schismatorhynchus, ダッ Bleck.

ammulata. $1 \therefore$ \& 1 .

$$
\text { キキ甘ョリ }
$$

ariastomella. C.d.I:

$$
\begin{aligned}
& \text { virescens, Schleg. } \\
& \text { メがカ装泉 }
\end{aligned}
$$

saira, Breroort.

サンマ 
Cobitis, Irt. .

山城周防武藏

taenia, $J$.

シマドダヤウ

Misgurnus, Lacép.

淡路 東京其他隨所

Anchilognathus, Bleek.

東京川城

anguillicamdatus.

ドダロ䲓魚 C'Antor.

肥前

intermedins. sidney.

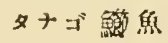

melmongaster. Blork.

モロコภ

rhombens. Silloy.

ホテ

limbatus, siden.

Leuciscus, Klein.

笽湖(稓棍) 早川(相摸)

haknensis. (tthir.

フカハラ(ウグヒ)

Leuciscus.

elongatus. Kitllame?

世口

Pseudorasbora, Bleek.

perver. Sithery.

Pseudogobio, Mleek.

esocimus, Silling.

カマッカ 


\section{$[20]$}

琵琶湖(近江)

Opsariichthys, Bicel.

東京 原都

琵琶湖

東等

Barbus, $r$ " platypus. Sidhey.

*1 $\rightarrow y$

mucinostris, Blisti.

八x

sieboldii, silley.

temminceii, Sidelen.

schlegclii, (thri).

ミゴ七 (ニゴヒ サイ 白魚

homogenes, Gthe.

トロ ペ

homozonus. Gthr.

Carassius, Nils.

慥所

amitus. $I$..

フ十 㓩急

Cyprinus, tht.

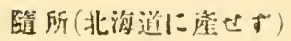
(itipio, $T$.

コヒ 鯖魚

I'amily Seopelide.

Plagyodus, steller.

虽摸 
Aulopus, $C u$.

japonicas, Gther.

Harpodon, Ies.

microchir, stthr.

Bathysaurus, lith.

mollis. Gther.

相摸

Saurida, $C$. \& $V$.

$$
\begin{aligned}
& \text { argyrophanes, Richurds. } \\
& \text { xy 狗四愿 }
\end{aligned}
$$

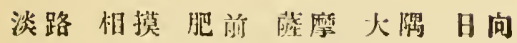

$$
\text { tumbii, Blenti. }
$$

\section{肥前}

Saurus, C. $V$.

肥 前

$$
\begin{aligned}
& \text { varius, l(íp) } \\
& \text { ナカブェ }
\end{aligned}
$$

$$
\begin{aligned}
& \text { myops. ('il'. } \\
& \text { ஃ×xy }
\end{aligned}
$$

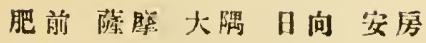

$$
\text { kamily Siluride. }
$$

Liocassis, Bleck.

longirostris. Fitler.

Pseudobagrus, Dleek.

aurantiacus, Silley. キが 即焦 
ransomnetii, Strind.

$$
\begin{aligned}
& \text { tokeinsis.? Thidrl. } \\
& \text { ギバチ }
\end{aligned}
$$

Silurus, . Art.

東京淡路 其他隨所

$$
\begin{aligned}
& \text { asotus, l. } \\
& \text { ナマズ 䱛魯 }
\end{aligned}
$$

Plotosus, Tacép.

$$
\begin{gathered}
\text { anguillaris. Bloch. } \\
\text { シマギ・゙(サシキ・゙、ゴンゼイ) }
\end{gathered}
$$

肥并相摸薩摩大隅日问

$$
\begin{aligned}
& \text { ORdel anaCanthini. } \\
& \text { Axacanthixi Pleuronectonde } \\
& \text { Fumily Pleuronectidu. }
\end{aligned}
$$

Pleuronectes, Art.

$$
\begin{aligned}
& \text { asponimus. Solle! } \\
& \text { サメガレ }
\end{aligned}
$$

多疼肥的

$$
\begin{aligned}
& \text { Variegatus. Sihle! } \\
& \text { ホシガレ }
\end{aligned}
$$

身京溥肥前

rolohamae, Gthe.

東京㩐

Pseudorhombus, Blect.

cinnamoncus.

カ゚ンリウがレヒＳＳhlen.

肥前淡路上總

olivaceus. Sehley.

ヒラメ

肥前淡路 
oligolepis, Bleel.

長崎

russellij, Gru!.

pentaphthalmus,

Githr.

瀨户內海

Parophrys, (iirerd.

能前

cornuta, sichleg.

メイダレヒ

Rhomboidichthys, Bleet:

myriaster, Blorli.

昍前

grandisquama.

sichleg.

紀俶肥前

Cynoglossus, Cuv.

interuptus, Gthr.

ウマノシタ

joyneri. Githr.

東京彎

Synaptura, Cant.

相模

zebra, Blork.

シマガレヒ

japonica, Bleck.

肥前 
Plagusia, Schlerg.

肥 前

$$
\begin{aligned}
& \text { juponica, Sthley. } \\
& \text { ウシノシタガレ }
\end{aligned}
$$

Solea, $M$. if $A$.

japonica, Silheg.

肥解计豆

\section{ANACANJHIXI GADOIDEL.}

frimily Marmida.

Macrurus, Bloch.

japonicus, sihley.

トロジン

杷前相摸荿䐴

paralleius, (Gthr.

租摸洋

asper. Cithr.

䄄摸洋

nasutus, (othr.

相摸洋

longitilis, Gthr.

性摸注

villosus, Gthr.

㥵摸洋

altipimis, (ithr.

相摸洋

lincephalus, Gilu.

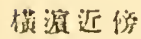




\section{macrochir, Gthe.}

相摸洋

tokiensis, Dörl, \&f

Steind.

Coryphaenoides, Gunner.

marginatus, Dödrl.

Finnily Atclopodide.

Ateleopus, Schle!

初摸

japonicus, Bleck.

シッ゙ッチコ

Fanily Opluidiidu.

Brotula, (:

multibarbata, 18千 Sehleg.

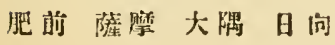
japonica, Döderl. de Steind.

Sirembo, Bleel:.

imberbis, Schley.

肥 前 armata, Schleg.

盵前

Neobythites, Good i Beau.

graudis, Gthr.

橫湲近䏁 
Pteroidonus, $C t h r$.

"puinquarius, Gthr.

Myxocephalus, Död $\%$ (f Steind. jatponicus. I Iülrl. af

siteind.

Fierasfer, ' ' $u$.

kagoshimanms.

I)iill.

麇兒島

\section{Fumily radider.}

Gadus, $A r t$.

陸前北海道

hrandtii, Milyd.

\& 大口詹

chalcogrammmus.

$$
\text { スケトウタラ I’ull. }
$$

越後 少房

乘京枯境

$$
\text { minot: Mndil. }
$$

Lotella, Kaथp.

phycis, sichlen.

$$
\text { インアイカメ }
$$

鿱前

Physiculus, K(a)p.

killu)i. I'ue!y.

Leucosparion,

絮得周防筑前

petersii, Hilyd.

シラス(シロウキ) 
Motella, Cux.

pacifica. Sihleg.

肥 前

Haloporphyrus, Githr.

inoshimae, Gthr.

相摸

ORDER ACANTHOP'TERYGH PHARYNGONATHI.

Family Emlnotocyde.

Ditrema, schleg.

temminckii. Bleck.

ウミタナゴ

相摸安屋肥前

Neoditrema, Steind.

ransonnetii, Steind.

東京酸?

Fumily Tadride.

Pseudoscarus, Bleeli.

$$
\begin{aligned}
& \text { oviforms. } \\
& \text { アキプダヒ (+ベロり) } \\
& \text { globiceps. C. I. }
\end{aligned}
$$

Cirrhilabrus, schle\%.

temminckii, Bleek.

肥前

Duymacria, Blleek.

浥前

flagellifera, Blceli.

デンン゚クサビ 
spilogaster, Ileck.
クッペラ

長崎

Labrichthys, li/eel.

性摸安原肥前

$$
\begin{aligned}
& \text { rubiginosa. Sithley. } \\
& \text { カナペラ(アカペラサ、ノハ) }
\end{aligned}
$$

gratcilis, Inield. d:

Strind.

Chaeropus, $(\therefore) 1$.

安房

Cossyphus, $\therefore$. 1 .

japonicus. $C^{\prime}$ a $l$. カンダ

mimaculatus. (ithe.

Sennicossyphus, 'ithr.

reticulatus, Sidli!y.

$$
\text { コプン }
$$

安房肥的

robechi. Steind at

$$
\text { Diillil. }
$$

Callyodon, ( $\therefore$ ، 1 .

japonicus. $(\vdots a t)$ r.

プタ゚ヒ(ザ゙メロり)

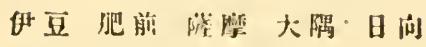

Novacula, '. ‘ $V$.

安原相摸盵新 deas. Sibley.

ティシ(テンス) 


\section{[ 29]}

Platyglossus, Klein.

$$
\begin{aligned}
& \text { poecilopterus. } \\
& \text { アョベ Silleg. }
\end{aligned}
$$

安序肥前

prrthograminus.

イトバラ Sidhey.

安居淡路肥前

$$
\begin{aligned}
& \text { bleckeri. Mirdel a } \\
& \text { steind. }
\end{aligned}
$$

Julis, $1 \%$

$$
\text { aupido. sichle\%. }
$$

肥新

\section{Fumily l'omecentrider.}

Amphiprion, 137. Sclru.

紦什淡路

$$
\begin{aligned}
& \text { clarkii. brmo } \\
& \text { アプラロ }
\end{aligned}
$$

Pomacentrus, $C .1$.

$$
\text { dorsalis, Gill. }
$$

Heliastes, $C . I$.

$$
\text { notabis, Schleg. }
$$

Lophotes, yiorna.

$$
\text { capellei, schlcg. }
$$

肥䛔 
AC.IN'I'HOPIERYGII LABRANTHIBRANCHII.

Finmily Ialugrinthici.

Polyacanthus, K. $\pi .1 \%$

沖䅨本息

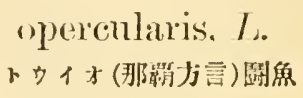

Fimily tiolnesocida.

Lepadogaster—.

minimnss, / hïld.

Fomily Solathanthi.

Notacanthus, tilo $\%$.

rissomums $l \div$, 1 .

Centriscus, $L$.

相摸

gracilis, lour.

サギブへ

scolop)ax. $l$.

Amphisile, Kloin.

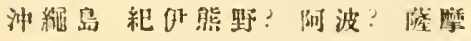

$$
\begin{aligned}
& \text { scutata. l. } \\
& \text { アギウキ(ヘコウキ) }
\end{aligned}
$$

\section{Frmmily Fistulariedes.}

Fistularia, I. .

紀做变居淡路肥斯

serratis. Ćur. ヤガラ火简嘴

depressa. Gthr. 
Family Gasternsteide.

Gasterosteus, $L$.

函籍

$$
\begin{aligned}
& \text { pungitius, } L \text {. } \\
& \text { トダッキ }
\end{aligned}
$$

$$
\begin{aligned}
& \text { noveboracensis, } \\
& \text { イトゥ尹 C.\&I. }
\end{aligned}
$$

越惓

$$
\text { Family Mugilide. }
$$

Mugil, .fr.

cephalotus. C. di I. ポラ(ナョシ)鲌魚

東京游岁房相摸淡路肥前薩摩大隅日向

haematocheilus,

$$
\text { x+口青魚 } T . \& S \text {. }
$$

東宗謷 犱前

joyneri, Githr.

東宗灣

\section{Family Atherinide.}

Atherina, cis.

bleekeri. Gthr.

束京灣相摸 肥前䧈縻大隅日向

Family Spheprenenider.

Sphyraena, .l.t.

japonica, $C \cdot d \cdot$.

淡路肥前薩摩大隅日向相摸 
肥前隊摩大隅日向

肥前裙摩大限日向

nigripinnis. 'T', S.

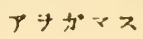

olotusatat. ('. I I.

$$
\text { セがマ? }
$$

Femily Blemnirde.

Centronotus, Bleeli.

舰前重京路

nebulosus, $T$. d S ギンポ

roscus, l'ull.

千島

Gunellus, (uv.

crassispina. Scliley.

肥前

Stichaeus, $C$. \& $V$.

易原㩐

hexagrammus.

sillili!y.

Clinus, Cur.

polyactocephalus.

ンタクヂィ I'ull.

Dictyosoma, $T \cdot S$.

安房

temminckii. Bleck.

ダイナンギンポ

Family Heterolepidotider.

Agrammus, Citho.

東京灣

schlegelii, Gthr.

グメ 


\section{[ 33 ]}

Chirus, Steller.

hexagrammus,

フイナ

Pall.

東京灣相摸

lagocephalus, Pall.

千岛

Family. Cepolida,

Cepola, $I$.

薩摩相摸䍃伊肥前

krusensternii, T.\&SS. アカタチ(ケかヒモりウグウノタヒマッ)

schlegelii, Bleek.

Family tobuider.

Amblyopus, $C . \& V$.

lacepedii, $T$. $\&$ S.

ワラス标(メナシウナギ)

東京芝浦筑後柳川

Eleotris, Gronov.

oxycephala, Schleg.

肥角

olscura, Schleg.

オホハゼ

Trypauchen, Cuv \& $\mathrm{Val}$.

vagina, $B l, S c h n$.

Periophthalmus, Bleer.

東京周防筑後柳川

modestus, $T . d S$.

トビハゼ泥狄 
koelrenteri, I'all.

小笠原岛

Boleophthalmus, $C$ \& $V$.

pectinirostris, ムンゴコロ Pichards.

肥前 筑後

Callionymus, $L$.

longecaudatus,

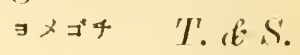

肥前

altivelis, Schleg.

大村海 (C. F.)

huguenii, Bleek.

長婍(C. F.)

東京㴬

$$
\begin{aligned}
& \text { curvicornis, C.\& } V \text {. } \\
& \text { 子メ゙ワポ }
\end{aligned}
$$

lunatus, Schleg.

肥前

Tridentiger, Gill.

淡路肥前

obscurum, T. is $S$.

$$
\text { トラ八甘 }
$$

Gobisoma, Girard.

macrognathus,

Blect.

Rivers of Yedo.

Gobius, $A v t$.

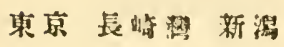

flavimamus, $T \cdot$. 八㙂 
肥 解

brunneus, T.\&S.

クロハゼ

hexanema, Bleel.

長崎

yokohamae, Gthr.

啮㵠 (Chall.)

艮崎（C. F.)

virgo, $T . d S$.

ベラハゼ

pflammii, Bleck:

肥前

River of Yedo.

symnauchen, Bleek.

polynema, Blect:

肥前

hasta, 'T. \& S.

アカハゼ

olivacens, T. d.S.

Finnily Pégasider.

Pegasus, $I$.

相摸紀伊䮚河

draconis, $I$.

ウミテック

Family Cetaphlucuti.

Dactylopterus, Lacép.

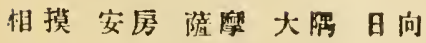

orientalis, $C . \& I^{r}$.

七るホウボウ 


$$
\text { [36] }
$$

Peristethus, Kinup.

要房肥前

orientale, $T$. \& $S$.

ッノカガシラ

$$
\text { Fumily Coltider. }
$$

Bembras, $C$ of $l$.

安展

japonicus, 6 . If 1 .

$$
\text { フカコ }
$$

curtus, $I . \& S$.

吧前

Trigla, Art.

药居

淡路相摸

Lepidotrigla, ${ }^{\prime}, \& \cdot I$.

肥前

bürgeri. 'T'. \&S.

キニカカガシ

lomgispinis. Dodurl di Steind.

microptera, Gthr. カナがシ 火焦

相㩲穻原

Prionotus, (I.acip) (C. I r

肥前 
Hoplichthys, $C$ \& $V$.

相摸薩糜肥前大满日向

langsdorffi, T. C.S.

ハワコ゚チ.

Platycephalus, $B l . S c h n$.

淡路 東菒灣

insidiator, Forsk.

コォ 作尾魚

spinosus. T. $d$.

把 站

asper, $C \cdot d \cdot$.

肥前

犯 前

macrolepis, Bleeli.

ア尒ザチ

inttatus. 'I'. a' S.

メゴチ

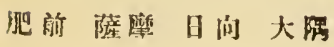

japoniens, Tiles.

管摩

rudis, Githr.

キナゴチ?

punctatus, C. C I.

Centridermichthys, Rivbras.

fisciatus, Heclel.

percoides, G thr.

$\checkmark 5 タ ゚ ஃ$ 
affinis, Dürlrl. \&

Stcnid.

argentens. Dörll.

elegans. Steind.

schlegelii. Düdri.

子ギノマ(三崎方善)。

nudus. Dïdrl.

marmoratus, Dödrl.

Cottus, $1 \%$.

intermedius, T.\&S.

bathybius. Githr.

South of Yedo, (Chall.)

remii. Shilgh.

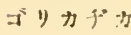

hilgentorfii, Jüirl.

Halieutæa, $C$ \& $I$.

Family Pediculati.

相损 肥 的

stellata, Wihl.

クフンンウ（イロナンコサ） 
Ceratias, Kröyer.

$$
\text { carunculatus, Gthr. }
$$

South of Yedo, (Chall.)

Chaunax, Lowe.

pictus, Towe.

相摸

Antennarius, Commers.

marmoratus, Bl. Schn.

ハナラコセ

大坂㩐肥前

tridens, S. \& T $T$.

イジทタ

㥸前

prinniceps, $C . \& V$.

Lophius, Art.

setigerus, Wahl.

アンコウ 華瞵㷛

相摸肥沶

Fumily Truchinider.

Prichodon, Steller.

欧田

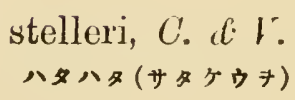

Latilus, $C \cdot d V$.

argentatus, $C . \& V$.

アマダ七 少頭魚

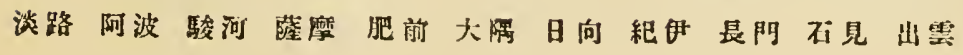




\section{[ 40 ]}

Sillago, Cиє.

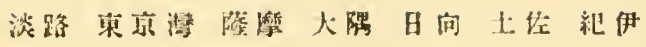

japonica, 'T'. S.

Y

sihama. Forsli.

Percis, Schneid.

皱詶肥前

pulchella, S. \& $T$.

トンコロイワ

Neopercis, Steind \& Dödrl.

multifasciata, Iö̈drl.

เ $5 キ ゙ ス$

sexfasciata, $S \cdot d$. $T$.

ト5キス

aurantiaca, Dödrl.

フォス

Champson, rithr.

volax, Githr.

相摸櫭

Anema, Cithr.

肥 前

elongatum, T. \&S'

アョ、コゼ(垁原氏

inerine, $C \cdot \mathbb{E} V$.

ミシマキコゼ

淡路相摸

Uranoscopus, $L$.

安屌

asper, 'I' d s.

デンモンダイワコぜ 
爬 前

bicinctus, $T$. \& $S$.

メガアウ $\Rightarrow$

Family Siombride.

Echeneis, Art.

乘宗激 肥前

naucrates, $L$.

コバンザメ（コバイタ、゙キ）

brachyptera, Lowe.

㸭前

remora, $I$.

肥前

albescens, $T$. \& $S$.

相摸肥前

Elacate, $C u v$.

相摸

nigra, $B l$.

不

Cybium, Cuv.

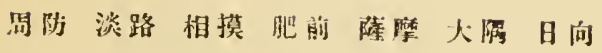

niphonium, C.\& $V$.

サロ 㷂䂭魚

chinense, $C . \& I$.

オサロ

岁展相摸

tapeinosoma. Bleet.

薩磨大限 日间相摸现前

ソウダガッキ

Pelamys, $C$. if $V$.

orientalis, T. \& $S$.

肥前薩摩日问大隭相摸

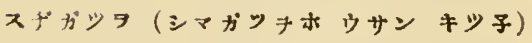


Thynnus, C. \& $\%$.

$$
\begin{aligned}
& \text { thummina, } C \cdot \delta \cdot V \text {. } \\
& \text { スレ (ヨコロか゚ッョ) }
\end{aligned}
$$

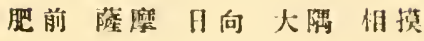

$$
\text { pelamys. } C \text {. if } 1 \text {. }
$$

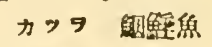

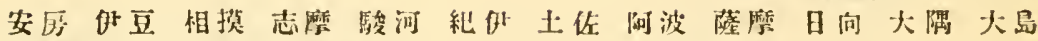
(隡㩐)

$$
\begin{aligned}
& \text { albacora, Lour. } \\
& \text { キハダマグロ }
\end{aligned}
$$

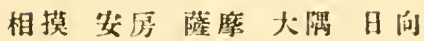

$$
\begin{aligned}
& \text { macropteris. 'T'. dS' } \\
& \text { ピンナが }
\end{aligned}
$$

肥前相摸

$$
\begin{aligned}
& \text { sibi, T. \& } S \text {. }
\end{aligned}
$$

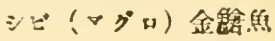

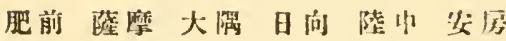

Scomber, lit.

janesaba, Blecti.

$$
\text { マルサパ }
$$

瞣後白杵肥前

\section{Scomber.}

preumatophorus.

サバ De le Rodle.

loo, C: I:

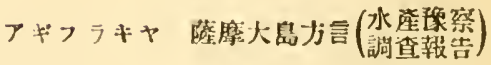

schlegelii. Dïtrl of

steind.

tapeinocephalus,

七ラサパ

Bleck.

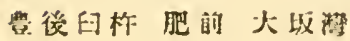




\section{Family Coryphlacenider.}

Mene, Lacép.

maculata, Bl. Sichn.

Lampris, lietzius.

相谟

luna, Duhamel.

アカマンポウ

Brama, (Schneid.) Risso.

相摸

相摸

相摸

$$
\begin{aligned}
& \text { laii, } B l . \\
& \text { シャガッ }
\end{aligned}
$$

$$
\begin{aligned}
& \text { japonica, Hilyd. } \\
& \text { アンザイシ7 }
\end{aligned}
$$

longipimis, towe. エ校シダ

Coryphæna, $(A r t). C . \& \cdot V$.

hippurus, (L.)

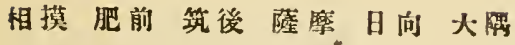

シイラ(クマビキ タウヤク)

Pteraclis, Gronoov. "(Centropholis.)

petersii. Hilgend.

相摸

Family stromateidu.

Stromateus, Art.

\section{淡路}

argenteus, $B l$.

マナガッウ

- Centrolophus, Lacép.

相摸?

japonicus, Dödrl.

$$
\text { メダ }
$$




\section{Family Ciytride.}

Zeus, $L$.

怚摸肥前

町模肥前

Autigonia, Lowe.

$$
\begin{aligned}
& \text { japonicus, C. \& I. } \\
& \text { カイターキ(マトゥの) }
\end{aligned}
$$

nebulosus, T'. \&.S. ガ゙ミダ

caplos, Гowe.

$t=4^{\circ} \mathrm{t}$

F'amily r'asongider.

Equula, $C$.

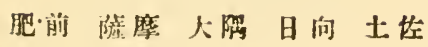

nuchalis, Schleg.

ギチ

rivulatit. S'chleg.

腿 前

Platax, $C$. : $V$.

teira, Cuv.

ッバクラダ七

Psenes, $C$. i $V$.

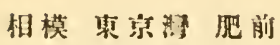

anomalus. ' $L$ '. \& $S$.

イボダ

Trachynotus, (Lacép) $\therefore \cdot$.

melo, Ridhurds.

现 前

Chorinemus, $\therefore$. \& $V$.

orientalis. T. of S.

昵 前 
Naucrates, $C$.

$$
\begin{gathered}
\text { ductor, } L \text {. } \\
\text { ヒメイナダ }
\end{gathered}
$$

Seriola, $C$.

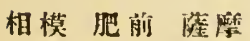

lalandii, C. \& I .

トラマサ

dumerilii, Risso.

カンハチ（シす）

安房薩陪

quinqueradiata, 'T. $\& S$.

ブソ(イナダロラサ）

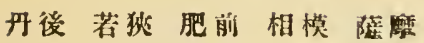

intermedia, T. \& $S$.

跑前

cristata, Dödrl.

相模?

Caranx, Cuv.

安原相模肥前

$$
\begin{aligned}
& \text { muroadsi, T. if } S \text {. } \\
& \text { ヘロアヂ }
\end{aligned}
$$

maruadsi, T. \& $S$.

マルアミ゙

安屏肥㷙

hippos, $L$.

シャアヂ

相模

ciliaris, Bleek.

イトマキナヂ(カンザシダヒ)

紀伊安原

equula, T. $\& S$.

ヒラアダ

安屏肥前 
[ 46 ]

torvus, Jenyns.

メケギ

delicatisimus, Döderl.

rottleri, Rüpp.

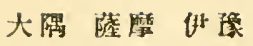

Trachurus, 1 . \& $F$.

相㷬 现前

$$
\begin{aligned}
& \text { trachurus, } L \text {. }
\end{aligned}
$$

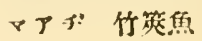

Family Acronuride.

Prionurus, Lacép.

性模肥献

$$
\begin{aligned}
& \text { scalprum, Langsd. } \\
& \text { =サダヒ }
\end{aligned}
$$

Naseus, Commerson.

unicornis, Forsl:.

肥前

Acanthurus, 1 \%l.

$$
\text { matoides, } C \text {. } \mathcal{E} I^{5} \text {. }
$$

肥前(?八昙路摩)

Fumily 'Trithuride.

Trichiurus, $L$.

lepturus, $L$.

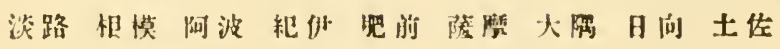

$$
\text { タチロォ带愿 }
$$


Lepidopus, Gonan.

$$
\text { tenuis, Gthr. }
$$

Thyrsites, C. $V$.

相模

$$
\text { prometheus, } C \cdot d V \text {. }
$$

Gempylus, $C . V$.

serpens, Saland.

Ruvettus,

相模安房上菟

$$
\begin{aligned}
& \text { pretiosus, Coceo. } \\
& \text { ハッムッ }
\end{aligned}
$$

Family Viphiida.

Histiophorus, $C$ \& $V$.

相模 肥前

orientalis, $T$. \& $S$. ヘもヨカダキ

gladins, Brouss.

メが゙キ 旗魚

相模土佐肥能北海道

Family Scicnider.

Sciæna, Art.

肥前薩摩相模淡路

$$
\begin{aligned}
& \sin a, C \cdot C V \text {. } \\
& \text { イシモす石首魚 }
\end{aligned}
$$

japonica, Schleg.

肥前薩摩大踝日向 


\section{[ 48 ]}

Corvina, $C$.

$$
\text { cuja. } \therefore \& \text { \& } r \text {. }
$$

Family Polynemide.

Polynemus, $L$.

multifilis, Schleg.

肥 前

plebejus. Gm.

ッバクラコノシロ(アゴナシ)

肥前相模士佐?

Family Kurtide.

Pempheris, $C$. $V$.

molucea, $C$. of $T$.

贬端

\section{lamily beryside.}

Holocentrum, $A r \%$

畹前

spinosissimum, T. $T . S$.

$$
\text { Aフトタ⿰ }
$$

rubrum, Forsli:

肥前?

Myripristis, $C$.

相模和沓

$$
\begin{aligned}
& \text { juponicus. C. \& } V \text {. } \\
& \text { キンダヒ キントキダ }
\end{aligned}
$$

Polymixia, Louce.

相悩 nobilis, Tone.

トンメタ́ 


\section{[ 49]}

Monocentris, Bl. Sclen.

安原相摸大息(伊至)

japonicus, Houtteyn.

マッカサウキ

Hoplostethus, $C$ a

mediterraneus, $C$. \& $V$.

ヒウチダー

安展落摩肥前

Trachichthys, Sllux.

d:u'winii, Golm.

何模

Beryx, $C^{\prime}$.

decardectylus, B. R. T.

II) 吕 (Chall.)

相摸

splendens, Lour.

キンメダヒ

F'tiully 't'mthide.

Teuthis, $L$.

相模肥前薩縻

allixpunctata, Schleg. $\gamma \in z^{*}$

fuscescens, Thoutt.

ギハギ

安示肥前

nebalosa. Guther.

ョッロリ (少管原)

小篻原父島

Fumily siongumiene.

Pelor, $C$ \& $T$.

aurantiacum, $T$. \&.

肥湔 
肥前

Synancidium, Miull.

肥前薩壁

Pterois, $C$.

淡路安原相模

Scorpæna, . lint

安原

(irrhosid $C$. . . I .

$$
\text { キニカサコ。 }
$$

timbriata. Thïlirl.

miostoma. Cthe.

kagooshimana, Dëdrl.

哭兒㤐

Sebastes, ${ }^{\prime} .1$.

$$
\begin{aligned}
& \text { inermis, } C \text {. of } I \text {. } \\
& \text { モョ(スミカサゴ) }
\end{aligned}
$$

倓篹

$$
\begin{aligned}
& \text { marmoratus c col'. } \\
& \text { 为 } \\
& \text { nivosun. Milyd. } \\
& \text { ゴマスギ（コ、゙メフギ） }
\end{aligned}
$$

erosum, C. d I I .

ダルマタコゼ

lumulata, $T$. d S S

ミノカサゴ

bleckerii. Möidr.

杖掑

japonicum, T.RS. 
vulpes, Dïderl.

dactylapterus De la Poche.

elegans, 'T'.

Tetraroge, $C_{i} t h r$.

町模肥前

rubripimnis, 'T'.

ニガウ

Iomgispinins, $C \cdot d: V$.

丹後

tirnianotus. Iaciep.

Minous, $C$. $V$.

pusilus. T. d.

嚾摩肥前

Aploactis, $T . \& S$.

aspera. T', \& S.

薩摩 肥前

Apistus, $C$ \& $V$.

alaties. $(\therefore, r . F$.

安原

jachycephalus, T'.c S'.

カミシモ(ケシモヨ)

rentricosus. T', IS.

安疗 但荧 
maxcoshine Gthr.

joynori, Cithr.

タケノコメバル

淡咯 相阵

oblongus, lithr.

matsubarax, Hilgel.

アコロ

相惔

Starches, Lrere.

梢摸

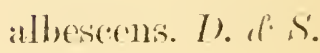
シェカサロ

fimmily rimhitile.

Chilodactylus, (lactp) ('.

抑摸!

monatus, 1 . of I.

タカルッ比

gibhosts, lichl.

相摸?

Cirrhites, ('ommers.

alureus. T. \& $\mathrm{S}$.

ホキゴンペ

奖原

Paracirrhites, Siciud.

jitponicus, Steind.

lannil!! Hophlesmethider.

Hoplognathus, likeli.

舰前王使

fasciatus. 'T. (f. S'.

イシダ七（シアヨコダヒ） 


$$
\text { [ } 53]
$$

相摸肥前

$$
\begin{aligned}
& \text { punctatus, } T . d \text {. } \\
& \text { イシガキダ }
\end{aligned}
$$

\section{Fremily sipurider.}

Chrysophrys, $C$.

肥前 紀伊

aries, $I$. di S.

- $3 *$ t

hasta, Blecli.

クロダヒ 烏頓魚

淡路相摸紀士伊土佐肥前東京塱

swinhonis, Gthr.

瀨戸內

Pagrus, $C$.

majol, 'T'. d $S$.

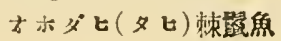

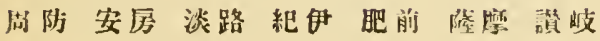

tnmifrons, T. $\& S$.

ヘナ・レダヒ

能登肥前紀伊

cardiualis, Jacép.

カスコ゚ダ匕

肥前 相模

Lethrinus, C.

hæmatopterus,

フメフキダヒ Richards.

相摸 小等原㫷

$$
\begin{aligned}
& \text { lichardsonii. } \\
& \text { ×イチダヒ }
\end{aligned}
$$

肥 前

nematocantlius, Blecli.

肥施 
Girella, Gray.

punctata, Gray.

スミヤキダヒ(メジダヒ)

相笑紀护安原

Pimeleplerus, (Lacép) C.

indicus, $C$. \& $I$.

相模

Finmily Mullida.

Upenoides, Bleel.

安原豊後伊憡

bensasi, 'T' (f S.

ヒメヂ (ベニサシ)

sulphureus. C. \& 1 .

japonicus, Houtt.

シメ(高知方窗?)

鹿兒島(D。)

Upeneus, $C \cdot d I$.

spiluns, Bleck.

肥 前

pleuraspilos. Blecti.

肥前？

安原

$$
\begin{aligned}
& \text { chrysopleuron, T'dゆS. } \\
& \text { アカヒメヂ (シシゴヒ) }
\end{aligned}
$$

dubius, 'T' of s.

肥新 


\section{Fomily Sigunaipinnes.}

Hypsinotus, $T$. \& $S$.

安房上總

rubescens. (ithr.

ヨコダヒ (シカクダ七)

Holacanthus, Lacép.

septentrionalis, T., CSS.

$$
\text { キンチャクダヒ }
$$

肥前相模薩磨

Heniochus, $C . I$.

土佬

macrolepidotus, $A r \%$

ハタタテダ

Chætodon, Art.

相模 隡磨

$$
\begin{aligned}
& \text { modestus, 'I' \& S'. } \\
& \text { ヤッヌダピ }
\end{aligned}
$$

$$
\begin{aligned}
& \text { aneus, 'T. \& } S \text {. } \\
& \text { テゥテウウ }
\end{aligned}
$$

旦 前

肥 角

$$
\begin{aligned}
& \text { strigatus, (Iangsd.) }
\end{aligned}
$$

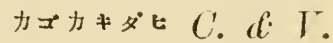

nippon, Dödrl.

安河 相模

Fomily Percide.

Anoplus. $T . \& S$.

banjos, Richards.

相模 
Pentaceras, $r . r$.

$$
\text { jirnonica, Döderl. }
$$

相模

Priacanthus, $C . d l$.

jarponicus, (Longsd.)

C. di $Y$.

相㷬

把前

$$
\begin{aligned}
& \text { niphonicus, } C . d V \text { V } \\
& \text { キンタラシダヒ (ダルマダ七) }
\end{aligned}
$$

bemmebari, T. If S.

$r$ 力

$$
\text { lubius, T. \& } S \text {. }
$$

肥前

haminu, Forsli.

相模

$$
\text { macrocanthus } C \text {. } Q V \text {. }
$$

Acropoma, T.S.

跑前

$$
\begin{gathered}
\text { japonicum, 'T'. } \\
\text { テンダクダ }
\end{gathered}
$$

Malacichthys, Mörle $\%$

grisens, Döderl.

相棬?

Chilodipterus, Jacép.

quingrelineatus, c.or.

薩㦄 
Scombrops, T. S.

japonicus, Dirderl.

$$
\text { クロ \. }
$$

相㷬

Niphon, $\therefore \& V$.

把前筑前相模

Apogon, $(\because) V$.

lineatus, T.

肥的柏模

senilineatus, T.dSS.

$$
\text { 子ブトダ }
$$

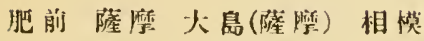

$$
\begin{aligned}
& \text { nigripinnis, C. @ } I^{r} . \\
& \text { ゴンゴロ ロ(三崎方言) }
\end{aligned}
$$

相模士佐

$$
\text { Elloti, Day. }
$$

土佐薩禁

$$
\text { bifasciatus, Rupp. }
$$

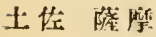

$$
\text { macropterns, Bllir. }
$$

\section{陸郴}

Apogonichthys, Bleet.

arinatus, $C . \&$. 
glaga. Bleeli.

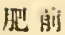

Erythrichthys, 'T.

-ahlogelii, tithr.

安嘚

Cypselichthys, Steind it Dërld?

相模大息(伊豆)

Synagris, Gthr.

sinensis, Lacij).

イトヨリ

相模淡路雕防土仿

japonicus, strimd if

$$
\text { タシぶ Jiidrl. }
$$

japonicus. bilme.

Dentex, $C$.

机㗛肥端

$$
\begin{aligned}
& \text { griseus, 'T. א. } \\
& \text { エピスダヒ }
\end{aligned}
$$

hypselosoma, lillir.

thmubergii, Lacij).

Scolopsis, $C$.

㓌縻 肥前

inermis, 'T'. \& $\mathrm{K}$.

タマガシ

japonicus, Bloch. 
Gerres, $C$.

oyena, Forsli.

肥前

japonicus, Bleel.

\section{肥前}

\section{Histiopterus,}

肥前相模

typus, Schley.

テングタヒ

acutirostris, schley.

肥前 性模 長阴

Diagramma, $C$.

pertusum. 'Thuml.

肥前

相模

$$
\begin{aligned}
& \text { punctatum, C. \& I . } \\
& \text { コロダヒ } \\
& \text { pictum, (T'hunb) } \\
& \text { C. d. I. } \\
& \text { cinctum, } T \cdot d S \text {. } \\
& \text { コセりダ }
\end{aligned}
$$

pecilopterum, C. C T .

Hapalogenys, Richards

相模

nigripinnis, $T$. \& $S$. セトダヒ

mucronatus, Eyd. \& Soul.

大阪知 
Pristipoma, $C$.

japonicum, C..

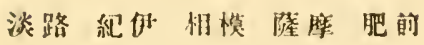

イサキ

hasta, Block.

肥 前?

Therapon, $C$.

肥前安厡

Glaucosoma, 'T. S

㸝前?

Döderleinia, stcind.

biirorei, Richurls.

ベニグ

orientalis, Hörlerl.

加知 川

Genyoroge, Cantor.

級俳壁摩

bergalensis, Bloch. スナ゙ウキ(ナナュウキ)

marginata. C. 6: I.

陮摩

livilata, C. \&. I.

Mesoprion, C.

安原

vittal, Ouoy de (raim.

キンをイイサキ

spalus, T? \& S.

肥前 
制

timoriensis. Qnoy \& Gaim.

anmularis, $C$ \& 1 .

Labracopsis, Dïde $\%$

jinponicus, Meiderl.

相模? 努原?

Pikea, Steinrl.

maxculata, Stcind. d:

Dëdil.

朴摸? 安厓?

Diploprion, ('. \& 1 .

Iifisciatum, $($. d I . s \pm y

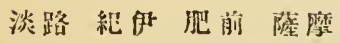

Aulacocephalus, $T$. .

sohlegrelii, Gthr.

安原

ay八

Plectropoma, ${ }^{\prime}$.

leopardinum, Lacép.

Serranus, 1 :

kawamebari, $T$. \& S S.

距淑?

trimuculatus, C.e. 


$$
\text { moara, } T . \text { ๙ }
$$

肥前 marsinalis, Jiloch.

把柿?

loxilgouatus Forst.

東京彞

土佐肥解

tsirimenala, 'T'. $r$ 力s

ala, \%. , i. S.

此剈

把

awoallal, 'I'. r' S'.

$$
\text { テキテ\% }
$$

dermopterus, $T$. d. $S$.

把 解

angularis. $($. I.

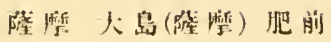

octorisetus, 'T' as'.

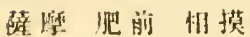

latifatsciatus, trar.

犯解

pacilonotus, I'dS'.

$$
\text { イトゴハタ }
$$

安原把削

alreoliatus, Forsli.

肥 刘? 
肥 榇 epistictus, I. I. S.

肥 前

肥前㥵摸努原

$$
\begin{aligned}
& \text { akatura, } T . S S . ~ \\
& \text { フッ゙キハタ }
\end{aligned}
$$

mystacinlts, Toey.

机摸

\section{肥前}

Anthias, $B l$. Schn.

jiaponicus, Dölerl.

相摸

作至统房

sehlegelii, Gthr.

と力サ甘゙

ilatraritacens.

$$
\text { Hiligel. }
$$

相摸?

Centropristis, '

$$
\begin{aligned}
& \text { hirndinaceus, (Laugsa) } \\
& \text { ヒメコダ七 C.. }
\end{aligned}
$$

肥前机摸奖房

Etelis, C.$V$.

肥前 


$$
[i \pm]
$$

Percalabrax, 'T' .

$$
\begin{aligned}
& \text { juyonicus, 'T' S. } \\
& \text { スス }
\end{aligned}
$$

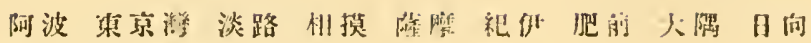

\section{Megaperca, Hilyent.}

$$
\begin{aligned}
& \text { ischinagi, Hilgend. } \\
& \text { イシナド }
\end{aligned}
$$

紀护 杖摸 


\section{ORDER ECAUDA'IA. SUBORDER PHANEROGLOSSA.}

Series A. Arcifera.

Fumilg Hylide.

Hyla, Lour.

arborea. I. rar. japonica, Schleg.

東京川口

$$
\text { アマカヘル 雨蛒 }
$$

\section{Family Bufonide.}

Bufo, Laur.

車京呰後淡路

$$
\begin{aligned}
& \text { vulgaris, Laur. }
\end{aligned}
$$

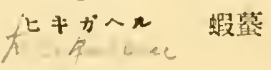

$$
\begin{aligned}
& \text { formosus, Blgr. }
\end{aligned}
$$

橫演

B. Firmisteñia.

Fumily Engystoinutidu.

Microhyla, T'schudi.

tissipes, Blgr.

沖樎岛

Fannily Rianiale.

Ixalus, $D$. \& $B$.

japonicus, Hull.

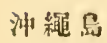


Rhacophorus, Kuhl.

$$
\text { viridis, Hall. }
$$

沖糏島

schlegelii, Gthr.

\section{岩代會津郡只見村 東京}

\section{Rana, $L$.}

果京周防

rugosa, Schleg.

ッチガへル

esculesta, L. var. japonica, Githr.

周防山口東京美港岥早㓋路

トノサマガール 金線霆

$$
\text { porosa, Copc. }
$$

神奈 III (C. B.S. 1S82)

japonica, Blgr.

アカジヘル 山蛤

東京淡路周防

沖綰島

martensii, Blgr.

(A. N.)
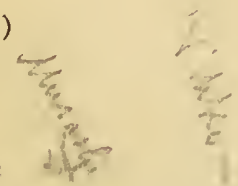

箱恨早川 武州秩父

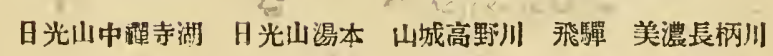




\section{CLASS REPTIIIA.}

ORDER OPHIDIA.

SUBORDER OPOTERODONTA.

Family Typhlogida.

? Typhlops. Schu.

sp.

宮古島

SUBORDER OPHIDII COLUBRIFORMES.

Family Colubridue.

A blabes, Darm.

semicarinatus,

Hallore.

沖繩島

Elaphis, Aldror.

果京大坂 淡路 北海道 長阴

virgatus, Sichley.

アフダイシヤッ 薑领蛇

quadrivirgatus, Boic.

シマへヒ $(+\star ร)$

車京箱根新息融津島淡路北海道周游

conspicillatus, boie.

チ゚ムグリ

東索大坂下默明光

Tropidonotus, $K m h l$.

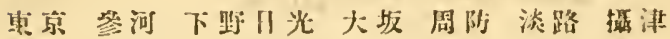

tigrinus. Boic.

ヤマガジシ 赫梀蛇

martensi, Hilgd.

ヒバカリ

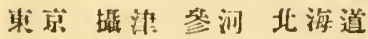


洲就請島

$$
\begin{aligned}
& \text { pryeri, Blgr. } \\
& \text { (ガラスーーバー沖䌒方言) }
\end{aligned}
$$

Fumily Lycodontide.

Ophites, Wagl.

$$
\text { japonicus, Gthr. }
$$

月光山湯本

\section{SUBORDER OPHIDII COLUBRIFORMES VENEROSI.}

Fetmily Hydrophider.

Hydrophis, Daud.

$$
\text { striata, Laud. }
$$

沖繩近海

$$
\text { bicolor, Dutul. }
$$

能登感至郡遠江御前岬出零

$$
\text { planidoides:- }
$$

油緎近海

Blaturus, Latr.

油螋近海

fasciatus, Dend.

$$
\text { エラプウナギ }
$$

\section{SUBORDER OPEDII VIPERIFORMES.}

Family Crotalide.

Trigonocephalus, Oppel.

blomhoffii, Boie.

マムシ 䠦蛇

加賀京都東京安屏八丈岛越後淡路北海道土传 


\section{$\left[\begin{array}{ll}70 & ]\end{array}\right.$}

Trimeresurus, Gthr.

riukiuanus, Hilgd. ハブ 飯匙监

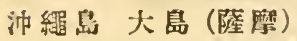

Bothrops, Wagl.

沖鼣岛

flavoviridis, Hallou.

\section{ORDER LACEPTILIA. \\ SUBORDER CIONOCRANIA.}

Family Lacertide.

Tachydromus, Daut.

tachydromoides, Schle!. カナービ

果京大岛(作豆) 箱根山

$$
\begin{aligned}
& \text { smaragdinus, Blgr. } \\
& \text { チシルヤーチー(沖䋖方言) }
\end{aligned}
$$

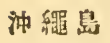

Fumily Scincide.

Lygosoma, Giay.

pellopleurum, Hallox.

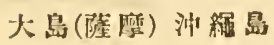

Eumeces, Wiegm.

marginatus, Hallox.

トカゲ 石龍子

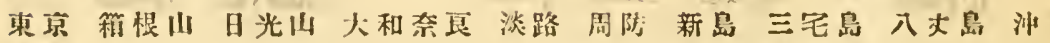
暒品 


\section{Family Aganidue.}

Japalura, Giay.

沖䊒島

polygonata. Hallou:

（アカタアー洲繩土名）

\section{SUBORDER NYCTLSAURA.}

Fuimily Geclonide.

Gecko. Laur.

japonicus. Gthr.

東京 筑前 䧓防 河內 辰門沖緆島

ヤ王等宮

Ptychozoon, Kuhl.

沖蛹諸島

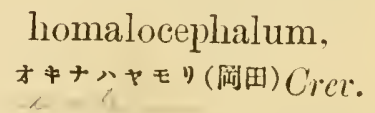

ORDER CHELONIA.

SUBORDER ANTHECÆ.

Family Spharide.

Sphargis, Mervem; T'ent.

丹後

mercurialis, Merrem.

$$
\text { ヤサバ(キサガメ) Tent. }
$$

\section{SUBORDER TESTUDINATA.}

Selies A. Cryptodira.

Group A. Digitata.

Fumily T'estuclinide.

Emys, Brongn. 
大阪西成郡

汹總島

Cuora, livay.

入更山品
$?$ sincusis, Gray.

$$
\text { クサガメ }
$$

? spengleri, Gruy.

オキナハガメ(ヤマガメ洲继方言) ambonemsis, $(t m y)$ マニママガメ

Gromp B. Lingata.

Litmily chronicur.

Chelonia, Zlem.

沛稳岛

imbricata, $T$.

タイマイ f青星

virjelis. 'T' d. S.

アョウミガ

小篮原鼠 神津島

(aollana, ITagl.

ナカシミ゙

妿展土住小篮原島

Series 1). Pleulomila.

\section{SUBORDER TRIONYCHOIDEA.}

Family Trimmehider.

Trionyz, Geoffroy.

japonicus, Sillegrl.

留兒島筑後川

$$
\text { スッポン 籍 }
$$




\section{[ 73 ] \\ CLASS AVES. \\ ORDER NATATORES. \\ Fumily Alcidre.}

Alca, $L$.

torda, $I$.

Wormon, Ill.

千岛祀室近海

$$
\begin{aligned}
& \text { cirrhata, } G m \text {. } \\
& \text { エトピリカ }
\end{aligned}
$$

corniculatum, Naum.

\section{千島}

Phaleris, Temm.

千岛

cristatella, Pall.

エトロフシミスズメ

camtschaticus, Lepechin. シモダウミスズメ(岡田)

下时(邚豆) 千息東京繳 psittacula, Pall.

千皇

pusilla, Pall.

加賀 箱管淡

Brachyrhamphus, $B r$.

umisuzume, 'T'cmm.

下田淡東京灣神渄島長崎下島鳥岛

antiquus, Gm.

東京灣千岛 
kittlitzi, $B r$.

東京灣 北海道

Uria, Mochi.

$千$ 最

carbo, I'all.

ハイマフリ

columba, I'cell.

千臭

箱舒近海

troile. $L$.

ウ ミ $\boldsymbol{t}^{*} ; 7$.

brumichi, Sulb.

ウガ

千息北海道横溜近游

Ceratorhyncha, $B p$.

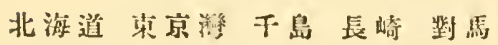

monocerata. I'cll.

$$
\text { ウトロ }
$$

\section{Family Colymbider.}

Podiceps, Iath.

北海道長崎仙落

cormutus, Gill.

ハジロカイップリ

cristatus, $L$.

橫演近伤箱筙近海

rubricollis. G Gm.

身京北游道沖緆血筑前

minutus, Lath.

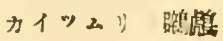


nigricollis, Brehm.

東京灣 北海道 長崎

Colymbus, $L$.

千兒北海道長崎

arcticus, $T$.

オホム

arlamsi. Gray.

箱辝長崎近海

sertemtrionalis, $L$.

フビ

東京北海道

Family Lemellirostres.

Cygnus, Bechst.

musicus, Bechst.

オホハクテウ

北海道手贺沼東京舟川青林維白石(㓌前)

Dendrocygna, $S w$.

javanica, Horsf.

沖絹岛

下總

bewicki, Yarr.

ハクテロ䎋

Anser, Briss.

㝠京周防

segetum, Gm.

ヒシクヒ 渇

東京周防加贺筑前

$$
\begin{aligned}
& \text { albifrons, } G \text { m. } \\
& \text { マカン (カリガそ) } \\
& \text { erythropus, } L . \\
& \text { コカリガチ }
\end{aligned}
$$

東京 


\section{$\left[\begin{array}{ll}76 & ]\end{array}\right.$}

北海道手贺沼独贺筑前

$$
\begin{aligned}
& \text { cygnoides, } L \text {. } \\
& \text { サカッラヒシクヒ }
\end{aligned}
$$

hyperboreus, Pall.

ハクカンン白萑

東京彎手驾沼 加贺

Bernicla, Steph.

hatchinsi, siw. a Rich.

シジウカラガン

手织沽千品崔城

$$
\begin{aligned}
& \text { nigricalls, (Tulkr) } \\
& \text { コクガン }
\end{aligned}
$$

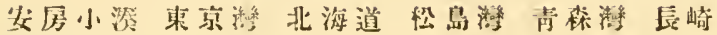
Anas, $L$.

boschas, $I$.

マがモ 兒

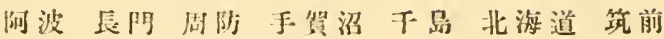
zonorhyncha, Swinh.

カガガモ

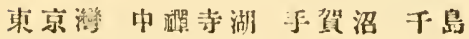

Aix, Boie.

galericulata, $L$.

ラシドリ 燃整

来京 周防 信浀 駿河 筑前

Carsaca, Bp.

rutila. I'all.

Tadorna, Brehm.

長崎 㮖演

$$
\begin{gathered}
\text { connuta, Gm. } \\
\text { ックシガモ }
\end{gathered}
$$

Mareca, Steph.

$$
\begin{aligned}
& \text { penelope, } T_{\text {. }} \text {. } \\
& \text { 七ドりガモ }
\end{aligned}
$$

東弶层峰北海道加贺 
Dafila, Steph.

手賀沼北海道日向大隅

$$
\begin{aligned}
& \text { acuta, } L \text {. } \\
& \text { キ十か、モ }
\end{aligned}
$$

Querquedula, Steph.

crecca, $T$.

コガモ 习鴨

來京千岛長崎沖稳岛筑前

東京市答 瀵筧

circia. $L$.

シマアシ

falcata, Tall.

ヨシガ

手賀沼長崎東京北海道肯森

formosa, Georyi.

フジカュ（トモへがモ）

手賀沼 東京 加賀

Spatula, lioie.

clypeata, $I$.

ハシビロがモ（クチがモ）

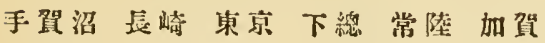
Chaulelasmus, $G_{r}$.

東京相摸

$$
\begin{aligned}
& \text { streperus. } I . \\
& \text { キカョシ }
\end{aligned}
$$

Fuligula, Steph.

東京 箱館 長崎 沖䋧島

$$
\begin{aligned}
& \text { marila, L. } \\
& \text { ナキハジロガモ（スズガモ） }
\end{aligned}
$$

mariloides. Tigors.

北海檤 横㜴

東京北海檤

cristata, $L$. キンクロハジロ 
北敏道横演

Nyroca, Flem.

東京北海道

Clangula, Flem.

北海道千易越後三面川

五息神系川北海道

Harelda, Lerr. $h$.

北海道下岛

Somateria, Leacle.

干岛

Oedemia, Flem.

岁居長涺(長阿) 北游道

北海道東京

Mergulus, Ray.

乘京上總北海道

Mergus, I.

東京手设沼北游道 glacialis, $I$.

lispar, Spurm.

ferina, $L$.

ホシハジロ

ferruginea, Gm.

フカハジロ（ヒフイガ

historionica, $I$.

シノリガて(キキノケンテら

glaucion, $I$.

木ホジロガ

fusca. $I$.

名另球

americana, lich.

クロトリ

albellus, $I_{\text {. }}$.

ミコフィサ

castor, $L$.

カハナイサ 
松島灣银崎千島

$$
\begin{aligned}
& \text { serxator, } L \text {. } \\
& \text { ウミフィサ }
\end{aligned}
$$

Family steganopodes.

Phalacrocorax, liriss.

東京

$$
\begin{aligned}
& \text { carbo, } T \text {. } \\
& \text { ウ 跑䠌 }
\end{aligned}
$$

相塻三崎狗田下島

$$
\begin{aligned}
& \text { pelagicus, Pull. } \\
& \text { ウガラス }
\end{aligned}
$$

bicristatus, Pall.

函馆横淈近仿

Pelecanus, $L$.

?phiìippensis, Gm.

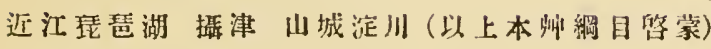

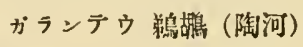

\section{?}

子ッタイテウ 箱鳥

小笠原島美濃（作八忘久》大風雨）后同地二獲タり㜖本、理科大學 ニ在り)

Sula, Briss.

leucolastia, Bodd.

カッキドタ(キサドリ)

八丈島小笠原島宮古島

Sterna, $L$.

fuliginosa, Gm.

\section{八重山岛}




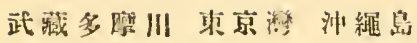

$$
\begin{aligned}
& \text { sineusis. Gm. } \\
& \text { アジサシ(アイタカ) }
\end{aligned}
$$

melananchen. 'T'emm.

沖稳鳥

$$
\text { dongalli. Momt. }
$$

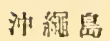

longipemis, Nordm.

北海道穔灌近伤千是

stolicla. $I$.

クロアジサシ(领岛)

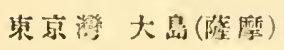

東京

シロアジサシ

Larus, $I$.

crassirostric, $I^{\prime}$.

ウミ子コ

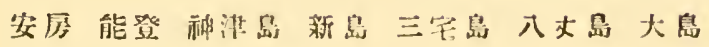

grlaucus, liallr.

箱 館

ジカメ

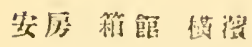

Elatucescens, Ticht.

ワシカれ

cachinnans, Pall.

橫望唇骀箱館

borealis, Br.

下聂

canns, $T_{\text {. }}$

北海道 
函館千島

marinus, $I$.

オホ七グロカきメ

leucopterus, Fabr.

北海道

delawarensis, Ord.

函馆

ridibundus, $L$.

工访无

東京北海道

tridactylus, $L$.

子飞唱京

Stercorarius, Briss.

parasiticus, $I_{\text {. }}$.

千島

crepiclatus, Gm.

千鼠

pomatorhinus, ' $I$ '.

東京灣

Fumily Trocellaride.

Attagen, Machr.

minor, Gm.

函馆

Diomedea, $L$.

derogata, Swinh.

リロア木ウドリ

北游道小管原島鳥上總 
Trachyura, Trimm.

アホウドリ 信天翁

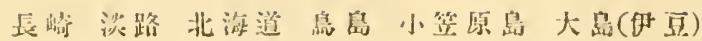

$$
\text { nigripes, Aud. }
$$

小四原箱馆長崎

Procellaria, $L$.

furcata, Could.

子岛

千島

lencorthoa, $T$.

ウミッバメ

Oestrelata,

Inypolenca, Sulvin.

小篮原舁

$$
\text { pacifica, Aurl. }
$$

千息撗濯

Puffinus, Birss.

grisetzs, Gm.

F是

letcomellus, 'T. if S.

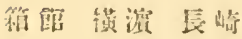

carneipes, Gould.

籍神

temuinostris, T. a S

yミs

初摸 


\section{ORDER GRALLATORES. \\ Fanily Charadriide. \\ Subfamily Charadritam.}

Charadrius, $L$.

多摩川 箱館 沖栕島

$$
\begin{aligned}
& \text { fulvus, } G m . \\
& \text { ムキグロシギ（アヒグロ） }
\end{aligned}
$$

Aegialitis, Boie.

cantiana peronii, Temm. シロチドリ（ナドリ）

行德(下總) 北海道

placida, Gray. イカルチドリ

東京中禪茮湖立山北海道

curonicus, G!m.

棌濯山中湖北海道

于显獚㴼 北海道

$$
\begin{aligned}
& \text { mongolica, Pall. } \\
& \text { ×ダイチドリ }
\end{aligned}
$$

\section{SUbFamiy Vaneldidire.}

Vanellus, $L$.

于贺沼 車京長崎 北海道

cristatus, Mey.

ナぶゲリ（イヌゲリタゲリ）

Lobivanellus,

inormatus, T. \& $S$.

真京手賀沼 筑前 ケリ

Squatarola, $C$.

helvetica, $L$.

東京 﨔演 北海道 


\section{[ 84 ]}

Subfanily Hematopodine.

Strepsilas, Ill.

interpres, $I$.

下䌆行德手贺沼安房千血北海道

キャウジヤウシギ(ムナグロシギ)

Hæmatopus, $L$.

osculans, Suinh.

ミヤコシギ(ミヤコドり)

下總行德 常陸 尾张 筑前

niger, Pall.

千岛

Family Scolopacida.

Subfamily Totanin.z.

Totanus, Bechst.

incanus, Gin.

松本千自沖鼣島

glottis. $l$.

フキアシチドリ

北海道 長崎

flavipes, (im.

武戴苗代湖

キアシシギ

ealidris, Bechst.

東京

fuscus. $I$.

東京 北游潧

ochropus, $L$.

チンロシギ

東京長崳北游道八大国

glareola. $\mathrm{L}$.

長崎北游道下自 
Tringoides, $B p$.

hypolencus, $L$.

東京北海道長崎千岛沖絕岛

Terekia, $B p$.

cinerea, Gm.

Limosa, Briss.

東京 北海道

lapponica, $L$.

コジヤクチドり

下總行德 手贺沼 北敏道

brevipes, Gray.

ソリハン、ギ

Recurvirostra, $L$.

avocetta, $L$.

Subfamily Tringine.

Tringa, $L$.

crassirostris, T. \& $S$.

称館于島榉演

canutus, $L$.

橫㴼

cinclus, $L$.

東京千島長崎北海道

acuminata, Horsf.

長崎北海道橫溜東京

行德(下總) 北海道長崎

ruficola, Pull.

トクみン 
subminuta, MFidd.

北海道千岛.

plat yrhincha, 'T'mm.

横罯 箱籍

Calidris, $C$.

arenaria, $T$.

橫潜 北海道

Machetes, $C$.

pugnax, $L$.

北海道

Lobipes, $C$.

hyperboreus, $L$.

北海道千自

Phalaropus, Briss.

fulicarius. $L$.

千耇

\section{?}

沖繩点

Eurinorhynchus, Nilss.

pyggmæus, $L$.

北海道橫溜東京行德(下總) 酒勾川河原

$$
\text { ヘラシギ }
$$

Surfamily Scolupaciñ.

Scolopax, T:

rusticola. $T$.

烃本箩士山東京北海道白川 ボトシギ 


\section{$[87]$}

Gallinago, $t$.

立川北海道富士川来京近傍

australis, Lath.

ヤマシギ? ォホヂシギ(飯)

scolopacina, $B$ p.

ヂシギ

東宗行德北游道

willsoni, $T$.

北海增 乘京

solitaria, Hodys.

ヤマシギ

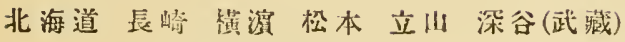

gallinula, $I$.

箱舘 横演近傍

Macrorhamphus,

griseus, (Gm.)

北游道横演

\section{Subfamli Numenisa.}

\section{Numenius,}

lineatus, $C$.

オホシヤクシギ

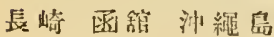

$$
\begin{aligned}
& \text { minor, 'T. \& } S \text {. } \\
& \text { シャクシギ }
\end{aligned}
$$

肥前手賀沼

$$
\text { cyanopus, } I \text {. }
$$

長崎 翼琵

東京長期 北海道

$$
\begin{aligned}
& \text { variegatus, Scop. } \\
& \text { コシャクシキ }
\end{aligned}
$$




\section{[ $\mathrm{SS}]$ \\ Family Herodii. \\ Subfamily Ibidinx.}

Ibis, $C$

乖京北海道

東京下總

$$
\text { niplon, } T . \leftrightarrow S .
$$

$$
\begin{aligned}
& \text { propinyua, Swinh. } \\
& \text { カマサギ (クットキ) }
\end{aligned}
$$

Subfamley Plataleixa.

Platalea, $I$.

lencorodia, $L$.

へョサキ 漫㗲

東京 箱舒 下總 筑前

$$
\begin{aligned}
& \text { minor, 'T. \& S S. } \\
& \text { ヘラサキノ一㮐 }
\end{aligned}
$$

五島長崎

\section{SUBFAMIL A RDFiñ.}

Nycticorax, Steph.

gुriseus, $L$.

セグロゴ井

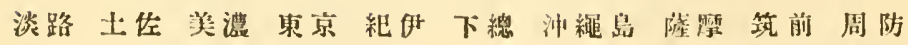

crassirostris, liy.

小笠原息

Goisachins, Puch.

melanolophus, Rafiles.

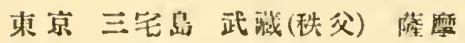

$$
\text { ミン゙コ\# }
$$

Botaurus, Steph.

東京手贺沼長拊北海道

stellaris, $L$.

サンカゴ゙ 
Ardetta, $B p$.

sinensis, Gm.

長崎 榉溜

$$
\begin{aligned}
& \text { eurhythma, Swinh. } \\
& \text { ョシゴ井 }
\end{aligned}
$$

犸因(武戴) 北海道限摩周防

Ardea, $L$.

cinerea, $I$.

ア・サギ青莊

日光山宇出津(能登) 東京長刳北海道沖繩岛

Herodias, Boie.

東京長崎北海道沖繩島

morlesta, Gray.
ダイサキ

alba. $L$.

束京 橫溜

長崎東京北海道紀湖大岛（伊豆）

intermedia, Wagl.

チウサギ（シマメグリ）

garzetta, $L$.

シラサギ（コサギ）䉆

東京

Bubulcus, Pucher.

長崎大坂紀仹東京上野前橋

coromandus, Bodd.

アマサギ 黄毛晸

Ardeola, Boie.

五岛對馬常陸行方郡神繩島

? sacra, Gm.

クロサキ

greyi, Gray.

沛恽島 
Butcrides, 1\%.

matcorhyouchus, fould.

ウシマッドリ?

長崄

Subamila Ciconis.s.

Ciconia, $L$.

下總淡路束京日们加賀

$$
\begin{aligned}
& \text { boyciama, Sirimh. } \\
& \text { エシッ゙ル 鹳 }
\end{aligned}
$$

\section{Subfante Grunas.}

Grus, I'ull.

加賀

cinerea, lirchst.

子ッ゙ミッ゙ル（クロッ゙ル）灰鹤

加贺

leucogeranus, Pall.

シロジル (ソデグロ )

北海道

japonemsis. Miell.

タンシウッ゙ル カ项鶴

東京阿波淡路间防

$$
\begin{aligned}
& \text { momachuts. Thinm. } \\
& \text { +ベッ゙ッ }
\end{aligned}
$$

lencutuchen, 'T'mm.

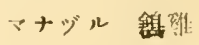

東京 北游道 筑䏸

伊豆尼张

$$
\begin{aligned}
& \text { virgo. } I \text {. }
\end{aligned}
$$

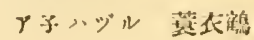




\section{[91] \\ Family Rallidue. \\ Subfamiry Palian.}

Rhynchæa,

東亲周防手贺沼長崎富士山

bengalensis. $T$.

タマシキ

Rallus, $I$.

東京下野松本 薩腾

indicus, Blyth.

クヒナ秋権

Rallina, Reict:

euryzonoides, Laffi.

沖繩島

Porzana, $V$.

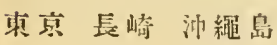

exythothorax. T. \& S.

ヒクヒ+

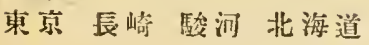

pyğmæa, Namm.

ヒメクヒナ

exquisita, Swinh.

シャクヒナ

北海道橫嚓

phreopyga, stej.

\section{八重島}

Euryzona, $B p$.

八重息

sepiaria. Stej.

Gallicrex, $7 ?$.

cristata, Tath.

長崎 
Gallinula, Briss.

東京 北海道沖䨀白 筑前

$$
\begin{aligned}
& \text { chloropus, } L \text {. } \\
& \text { バン 田稚 }
\end{aligned}
$$

Fulica, $I$.

$$
\begin{aligned}
& \text { atra. } I . \\
& \text { オホバン骨愐 }
\end{aligned}
$$

東京 脣崎 洲繩岛 筑前

$$
\text { Family Alectoride. }
$$

Otis, $L$.

伯者筑前下總石狩諌早(肥前)

$$
\text { tarda, } I .
$$

\section{Family Phasianide.}

Phasianus, $L$.

$$
\begin{aligned}
& \text { versicolor, } V \text {. } \\
& \text { キジ雉 }
\end{aligned}
$$

岩城東京淡路能登若猴周防駿河相模信濃护豆豊後

$$
\text { torpuatus, Gm. }
$$

$$
\text { カウライキシ }
$$

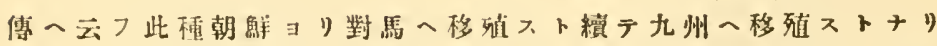
sœmmerringi, Temm.

$$
\text { 本州ヤマドッ(飯島) }
$$

剧防 武藏秩父 若规 立山駿河 美作

$$
\begin{aligned}
& \text { scintillans, Gould. } \\
& \text { 九州ヤマドリ(飯島) }
\end{aligned}
$$

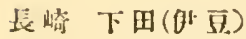

$$
\text { Fimily 'Ietruonide'. }
$$

Tetrastes, Keys.

$$
\begin{aligned}
& \text { bonasia, } I \text {. } \\
& \text { メジライテロ }
\end{aligned}
$$

北游道 
Lagopus, Briss.

$$
\begin{aligned}
& \text { mutus. Gould. } \\
& \text { ライデゥ }
\end{aligned}
$$

乘鞍岳 御岳駒ヶ岳白山立山蓮華山笠岳 Coturnix, Barr.

駿河東京北海道 japonica, $T \cdot \& \cdot S$. ウッ゙ョ communis, Bonn. ? ウッ゙ラ

長崎 橫溜近鮟

Turnix, Bonn.

blakistoni. Swinh.

$$
\text { ミフウッ゙ラ }
$$

沖繩島
ORDER COLUMBINA:

Family Columbida.

Columba, $L$.

岩手

livia, T'emm.

カハサハト

intermedia. Striclil.

沖繩島

宮古島

? indica, $I$. キンバト(アヤバト)

Turtur, Selby.

gelastes, Temm.

キジバト (ヤマバト) 㮩

東京富士川箱根山白杵八文島三宅島天草山口北海道沖繩 島

risorius, $I$.

東京近傍 


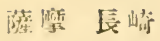

hrumilis. Temm.

ベニ゙ト

Treron, 1 .

sieboldi, Temm.

アキバト 年焦鳥

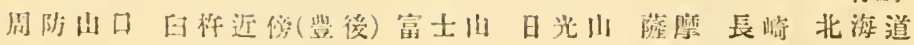

$$
\begin{aligned}
& \text { permagnil, Slej. } \\
& \text { キキトハrキバト }
\end{aligned}
$$

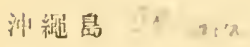

Carpophaga, selluy.

$$
\text { ianthina. 'I. d: S. }
$$

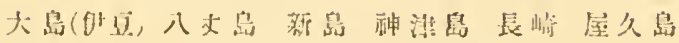

versicolor. Kittl.

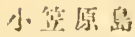

$$
\text { jorly. Stoj. }
$$

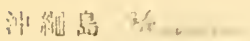

$$
\begin{aligned}
& \text { DRDER sid ASOURES. } \\
& \text { Finily cimblide. }
\end{aligned}
$$

Cuculus, $L$.

$$
\begin{aligned}
& \text { (a11)ills, } I \text {. } \\
& \text { カリコりドリ }
\end{aligned}
$$

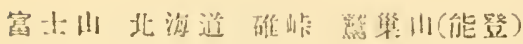

$$
\begin{aligned}
& \text { noliocephalns. Iath. } \\
& \text { ホトトギス 杜版 }
\end{aligned}
$$

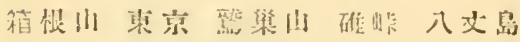

$$
\begin{aligned}
& \text { limmalayimus, I". } \\
& \text { ッ、トy }
\end{aligned}
$$

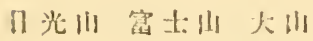

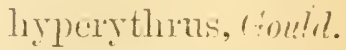

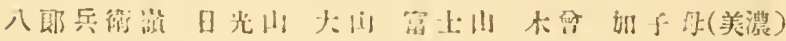

$$
\text { ジウイチ(マンハカリ) }
$$




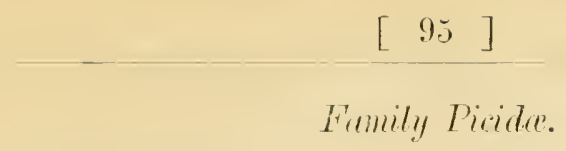

Dendrocopus, Koch.

japonicus, Seet.

富士山立山日光山下岛北海道乘主

$$
\text { アカゲラ }
$$

minor. $L$.

北海道

lenconotus subcirris, Stej.

刃ホアカゲラ

大和北海道

lenconotns namiyei. Stej.

大和

Iyngipicus, $E_{l}$.

kisuki, Temm.

コゲす

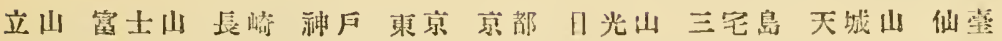
岩城

kisuki seebohmi. Hurgitt.

北海道 慬演 長崎

kisuki nigrescens, Secl.

洲繩島

Thriponax, C'ab. Hein.

richardsi, Tristrum.

ッシマリマゲラ(風国)

對馬

Picus, $\dot{L}$.

martius, $L$.

クマゲラ

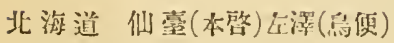

Saphiopipo, Hai,jitt.

沖絽兒

noguchii, seet.

バ゙ヂララ(敛鼻) 
Gecinus, Boie.

箱舘

$$
\begin{aligned}
& \text { cantus. Gm. } \\
& \text { ママダラ }
\end{aligned}
$$

awokera. 'T. \& S

アナグラ 川啾木

脣崎 横演 下野都贺䛍山中大和周防

Yunx, $L$.

japonica, Bip.

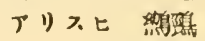

東京富士山長崎 北游道

ORDER PASSERES.

Tribe Levirostres.

Fumily Halcyonide.

Alcedo, $L$.

bengalensis, Gm.

カハをミ 魚狗

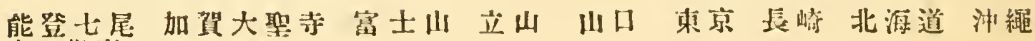
舁薩摩

Ceryle, Boie.

guttata. Vigors.

カプドリ（カアコドり ヤマタリ）花斑馬

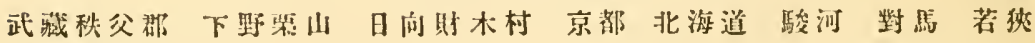
Halcyon, $S w$.

coromandia, Bodd.

ミヤマシヤウビン(ミッ゙ゴヒトリキャウロロ)

日光山東京近椁 北游道大和入重山品九州

日向踆河篮後

smyrensis. $I$.

ヤマシャウビン

Framily Corceider.

Eurystomus, 1 .

orientalis, $L$.

デッポウッゥ

長崎高野山武藏秩公公重山島 
Tribe Tenuirostres.

\section{Family Iprupide.}

Upupa, $L$.

信濃？伊勢

$$
\begin{aligned}
& \text { epops. } I . \\
& \text { マッガシラ }
\end{aligned}
$$

Family Meliphagide.

Zosterops, $V . \& H$.

japonica, $T$. \& $S$.

京東周防豊後淡路薩禁

メシロ 紼眼兒

? erythropleura, Swiul.

テウをンメジロ(コメジロ

屋久島(篒禽物語)

stejnegeri, Secb. オホメシロ

分文島大島三宅島新島

palpebrosa nicobarica, Blyth.

沖繩島

\section{Family Certhider.}

Certhia, $L$.

信濃大和下野北海道

familiaris, $L$.

$$
\text { キバシリ }
$$

\section{Tribe Fissirostres. \\ Fumily Hirnndidee.}

Hirundo, $L$.

東京山口淡路 駿河

gutturalis, Scop.

ッハクラ 燕

javảnica, Spartm.

沖繩島 
Cecropis, Boie.

東京

alpestris, Pall. アナグラッパメ(トックりッバメ)

Cotile, Boie.

根室

$$
\begin{aligned}
& \text { riparia, } L \text {. } \\
& \text { ス+ムグリツパメ }
\end{aligned}
$$

Chelidon, Boie.

dasypus, $B p$.

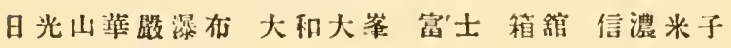

$$
\text { イワザメ }
$$

\section{Family Cypselide.}

Cypselus, Illiy.

日光山華繁憡布 北游道九州千岛

pacificus, Lath.

$$
\text { ナイリッバメ }
$$

Chætura, Steph.

飛驒 日光山北海道

caudacuta, Luth.

アマッパメ（カザキリッバメ）

Family Caprimulgide.

Caprimulgus, $L$.

jotaka, 'T. \& $S$.

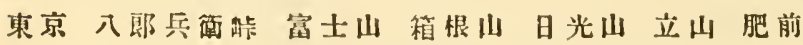

\section{ヨタ力 蚊四点}

Tribe Dentirostres.

Family Corcide.

Corvus, $L$.

macrorhynchus japonensis, $B p$. ヘシパトガラス 局程

長崎日光山東宗大島(阣豆) macrorhynchus levaillanti, Less.

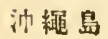




\section{[ 99 ]}

$$
\begin{aligned}
& \text { corone, } L \text {. } \\
& \text { ハシポソカラス(サトガラス)慈鳥 }
\end{aligned}
$$

東京立山沖繩岛?

$$
\begin{gathered}
\operatorname{corax}, L . \\
\text { ワタリガラス }
\end{gathered}
$$

東京(冬月稀ニ爽ル) エトロップ

埐崎

pastinator, Gould.

$$
\text { ミヤマガラス }
$$

dauricus, Pall.

木筸

$$
\text { コクマルガラス 燕烏 }
$$

neglectus, Schleg.

大坂 (Cat. of Birds.)

Pica, Briss.

筑前 筑後 肥前

pica, $L$.

ヒゼンガラフ（カササギ）鶕

Cyanopolius, $B p$.

東京模演富士山信濃

cyanus, Pall.

キナガドり 山鶕

Nucifraga, Briss.

caryocatactes, $L$.

ダケガラス（ホシカケス）

御岳栗山(下野) 日光山秩父制(武州) 富士山立山 Garrulus, Briss.

北海道

brandti, Evcrsm.

$$
\text { ミママカケス }
$$

japonicus, Sihl.

$$
\text { カケス(カシドリ) }
$$

相根山湯本(日光山) 富士山立山東京薩摩周防

lidthi, $B p$.

Jạpan(Cat. of birds). sinensis, Glil.

長崎 
Oriolus, $L$.

chinensis, Jerd.

デセンサグヒス 蒙息

筑前小吕岛屋久島大岛(薩州)

$$
\text { Family Sturnide. }
$$

Sturnus, $I_{\text {。 }}$

cineraceus, Temm.

ムクドリ 白顽登

東京 長崎 信潻

sericeus, Gm.

テシセンムクドリ

問々九州へ渡り来ルト云フ(趇物物語比野勘共)

Sturnia, Less.

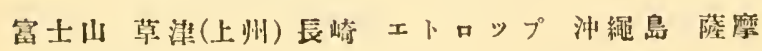

pyrrhogenys, $T \cdot \& S$.

シマムクドり(コムソ)

Family Lamiride.

Lanius, $I$.

bucephalus. 'T'. \&.S. モ天゙ 伯勞

笛士山日光山川口緂路東京長崎信澧八丈島 superciliosus, $T_{u t h}$.

篦士山 厂カ magnirostris, Less.

富士山橫涀近傍

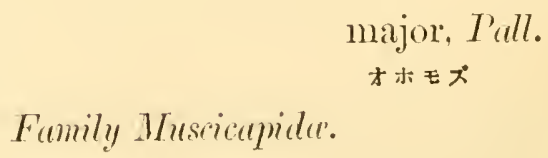

Cyanoptila, Blyth.

cyanomelicua, T'mm. オ机》竹林昜

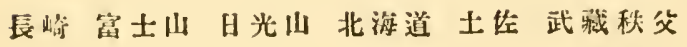


Butalis Boie.

latirostris, Paffl.

シ $₹ x^{\circ}$

信浱富士山日光山北海道千岛

siberica, Gm.

ฯゴ ご

臤河

Xanthopygia, Blyth.

narcissina, Temm.

* ヒ⿺夂⺀

富士山 立山東京 北海道 沖繩島

tricolor, $H a+t l$.

Poliomyias, Sharpe.

信濃 京郝 北海道

Inteola, Pall.

コッバメ(ムギマキ)

Tchitrea, Less.

princeps, Temm.

日光山東京近傍 富士山長崎信漕 筑前 サンクカウテウ 紫練 Pericrocotus, Boie.

cinerens, Lafi.

サンシヤウクヒ

日光山宾士山新島大和

? cantonensis, Suinh.

沖粕島

Ampelis, $L$.

東京近傍 北海道 白光山

garrulas. $L$.

キレンジャク 十二黄

japonicus, Sieb.

東京近傍 長崎 北海道 沖繩島 薩摩 


\section{Family Paride.}

Parus, $L$.

$$
\begin{aligned}
& \text { ater, } I . \\
& \text { ヒガラ }
\end{aligned}
$$

富士山 立山 北海道 沖繩島

palustris japonicus, Seel.

$$
\text { コガラ（ゴジウカラ） }
$$

立山富士山 長䗁八丈岛北海道伯者大山

$$
\text { varius, } T \text {. \& } S \text {. }
$$

$$
\text { ヤマがラ }
$$

北海道淡路周防豊後新島沖繩島會津朝日岳(米澤近浐) 新岛 三宅島神津島 筑前

$$
\begin{gathered}
\text { minor, } T . \& S . \\
\text { シジゥカラ 白媔鳥 }
\end{gathered}
$$

䍃士山立山八大品 長㥓 沖繩島會津 Acredula, Koch.

trivirgata, T. \& $S$.

東京近傍 富士山 㫳崎 立山银磨

$$
\text { エナガ }
$$

caudata, $L$.

シマエナカ

北海道青森近傍(管國博物館所藏息婹)

Aegithalus, Boie.

pendulinus, $L$.

長䛸

Sitta, $L$.

立山日光山札帨

amurenensis. Su:

キマハリ

Family Accentride.

Accentor, Boie.

rubidus. 'T'. \&S.

カヤクグリ（オホサ、゙ィ）

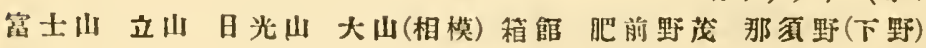


室士山白山乘鞍岳 五六狱(信濃)

$$
\begin{aligned}
& \text { erythropygius, Swinh. } \\
& \text { イワษバり }
\end{aligned}
$$

\section{Family Motacilide.}

Anthus, Bechst.

in aculatus, Hodg.

要士山長崎 北海道

$$
\text { ビンズ井 }
$$

japonicus, $T$. \& S.

$$
\text { タヒバリ }
$$

東京近㑨 北海道 薩摩

$$
\text { cervinus, Pall. }
$$

千島

\section{Motacilla,}

japonica, Swinh.

$$
\text { 七グロ ロ丰レイ }
$$

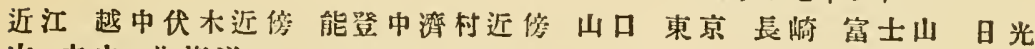
山立山北海道

埼玉近浐(武州)

$$
\begin{aligned}
& \text { lugens, Pall. } \\
& \text { ムナグロをキレイ }
\end{aligned}
$$

boarula, $I$.

$$
\text { キセキレイ }
$$

山口淡路 東京篦士山晹本 (日光山) 長崎北海道 三宅島 taivana, Swinh.

于島

sulphurea, Bechst.

沖繩島

\section{Family Sylviade.}

Acrocephalus, Naum.

果京富士山淺間原北海道

orientalis, $T$. \& S オホョシキり 剖㩰 
東京要士川 北海道

$$
\begin{aligned}
& \text { bistrigiceps, Swinh. } \\
& \text { コヨシキり }
\end{aligned}
$$

Cettia, $B p$.

$$
\begin{aligned}
& \text { cantans, T. \& S. } \\
& \text { ウグ ス }
\end{aligned}
$$

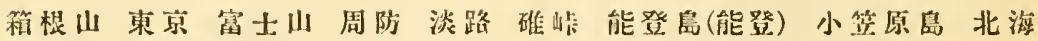
道長崎薩摩

$$
\text { cantilans, 'I'. d . S'. }
$$

菑士山日光山立山唇䗁横濱沖繩寔八重山岛

$$
\text { diphone, Kittl. }
$$

小箁原島

$$
\text { squamiceps, Swinh. }
$$

\section{篦士山}

Cisticola, Kєup.

$$
\begin{gathered}
\text { cisticola. ('Temm.) } \\
\text { セッカ(コノハドリ) }
\end{gathered}
$$

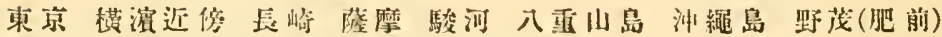

Megalurus, Mlorsf.

$$
\text { pryeri, Secboh. }
$$

静阔近傍模㴼近傍

Lacustella, Kíup.

fasciolata, Groly.

北游道

三肎岛北海道

$$
\begin{aligned}
& \text { ochotensis, Midd. } \\
& \text { シマセンニウ }
\end{aligned}
$$

lanceolata, 'T'mm.

北海道 
Lusciniola, Gray.

fuscata, Blyth.

Phylloscops, Boie.

coronatus, T. \& S.

センダイムシクヒ

富士山北海道 横演近傍 薩摩 新島三军岛

xanthodryas, Swinh.

メポン

日光山富士川北海道 沖䋗鸠

borealis, Blas.

コムシクヒ

長崎

tenellipes, Suinh.

函馆

Troglodytes, $V$.

fumigatus, Temm.

ミッ少ザイ巧婷鳥

東京富士山立山北海道薩摩 武藏秩父筑前

Regulus,

東京富士山 立山 薩摩

japonicus, $B p$.

キクイタズキ

Family Pycnonotide.

Pycnonotus, Kuthl.

小笠原嶋

familiaris, Kittl.

シマッジロ

-Femily Turdide.

Cinclus, Bechst.

pallasi, Temm.

カハがラス

立山日光山大谷川秩父(武藏) 富士山御岳近傍(信湄) 筑前 
Erithacus, $C$.

akahige, T'. \&S.

コマドリ

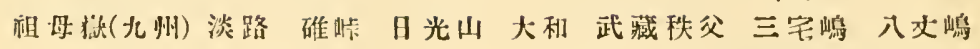
komadori, T. \& $S$.

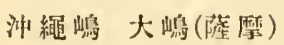

アカヒゲ cyaneus, Pull.

富士山日光山

コルリ

calliope, Pall.

ノゴマ(ノゴドリ)

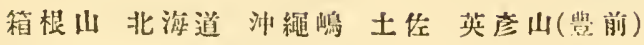

$$
\begin{gathered}
\text { シ } \\
\text { シマゴマ }
\end{gathered}
$$

石見(总便)

Tarsiger, Hodlys.

cyanuxa, Pall.

ルリピタキ

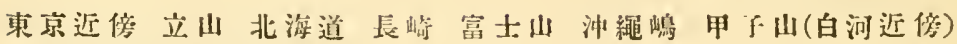
Ruticilla, Breh.

$$
\begin{aligned}
& \text { aurorea, Pull. } \\
& \text { ジヤウビタ } \neq
\end{aligned}
$$

薩摩山口長崎大息(伊豆)立山烃本東京近傍北海道 Pratincola, Koch.

富士山北海道箱恨川

$$
\begin{aligned}
& \text { indica, } B l \text {. } \\
& \text { ノビタ } ¥
\end{aligned}
$$

Pitta, $V$.

nymplha, $T$. \& $S$.

ヤイロングミ（朝鮮ツグミ）

嚾摩對品大隅

Monticolla, Boie.

solitaria. Miill.

イソヒヨドリ

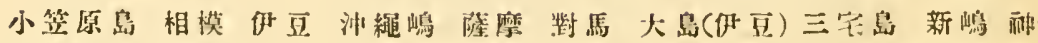
津岛

Hypsipetes, $V i y$.

束京蚛士山箱惟川立川新息三宅岛

amaurotis, 'T' d S S.

ヒョドり 白頭烏 
squamiceps, Kittl.

小笠原島

pryeri, Stejn.

沖繩岛

Geocichla, kuhl.

小笠原嶋

terrestris, Kittl.

シマジワビテウ（岡田）

Turdus, $L$.

sibericus, Pall.

マュジロ

富士山 日光山

pallidus, Gim.

山口東京長崎立山沖繩嶋八重山島

シロハシ(チヤジけイ

cardis. Temm.

薩摩 長崎富士山

クロッグミ ・・ダ)

nammanni. Temm.

八丈ッグ :

富士山 北海道沖䋎嶋

obscurus, Gmel.

天城山 立山富士山 長崎

chrysolans. Temm.

篦士心 日光山立山長崎 北海道沖繩鸠 アカーラ

fuscatus, Pall.

ッグミ(チヤウマ)

東京淡路長崎上野立山北海道薩摩大嵠(薩摩) 筑前 celænops, Stejneg.

三宅渪 入大嶋

フカコッコ（三宅嶋方言）

Oreocincla, Gould.

上野富士山

varia, $P$ ell .

ヌエジナイ（トラッグミ） 
Tribe Conirostres.

Family Alandide.

Alauda, $L$.

japonica, 'T' d's.

ヒバリ 天臹

箱极山富士山北游道東京山口筑前淡路

Otocoris, $B p$.

$$
\text { alpestris, } I \text {. }
$$

千喕 (Newton.)

Family Fringillide.

Emberiza, Briss.

ciopris, $17 p$.

水ジ口

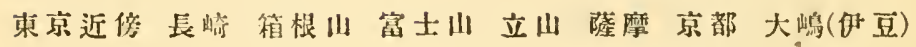
fucata, Pull. 林方

箱根山宾士心

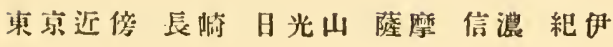

槛滥近傍箱馆立山東京

elegans. Temm.

ミヤマホホジロ

rustica, Pall.

カシラダカ

personata, 'T'mm.

アキジ藻惩

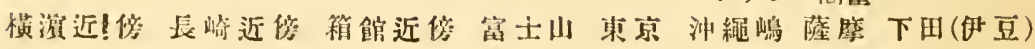
spodocephala, Pall.

東京近傍

北海道中湊(水吕)

anreola, P'ull. シマア习ジ(テウセンアキシ）

variabilis, 'l'cmm.

クロシ(スミヤキ)

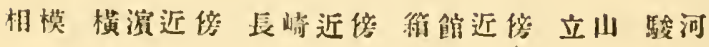


笛士山仙篦 薩摩

sulphurata, T. \& $S$.

ノジコ

rutila, Pall.

シマノジコ

神戶隡摩山川!金華山

yessoensis, Suinh.

ナべカムり（コジュリン）

東京近傍 匫河 箱館

schoeniclus palustris, Sar.

オホジェりン

㵠摩北海道筑波山

Plectrophanes, $T$.

$$
\begin{aligned}
& \text { nivalis, } L \text {. } \\
& \text { ウキホホジロ }
\end{aligned}
$$

箱館近浐

$$
\text { montifringilla, } T \text {.. }
$$

フトリ 花鴧

立山東京沖鶭島北源道筑前

Passer, Briss.

$$
\begin{aligned}
& \text { montanus, } I \text {. } \\
& \text { スズメ 篦 }
\end{aligned}
$$

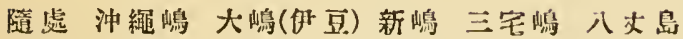

rutilans, 'Temmn.

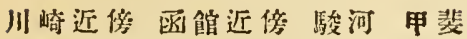

ニシナイスブメ 黄雀

Chlorospiza, $B p$.

kawarahiba, 'T. \&: S.

東京近浐 長崎近浐 薩孪

$$
\text { カハラヒッ }
$$

sinica, $I$.

コカハラヒハ

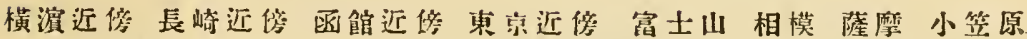
島三宅島

kittlitzi, Secl.

小篮原島 
Chrysomitris, Boie.

$$
\begin{aligned}
& \text { spinus. } L . \\
& \text { マヒハ 金翅雀 }
\end{aligned}
$$

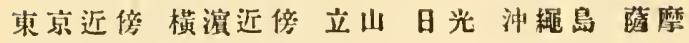

Linota, $B p$.

北海道日光山

北海道

Leucosticte, $S w$.

信漕松本函館近修千島下野日光

Corpodacus, $i$ (un $p$.

立山北海道

Uragus, Keyss. \& $\mathrm{Bl}$.

日光山箚士山北海道

Pinicola, $V$.

干后 福走(駿河)

Coccothraustes, Briss.

長崎信濃松本立山

長崎箱籍立山富士山薩摩筑前

山口近傍東京 linaria, $t$.

ベニもハ(メカヒハ)

?rufescens, Viell.

$\sqsupset \sim ゙ ニ$ 七

brumneinucha $\mathrm{Br}$. ハギマシコ

roseus, Pull.

オホマシコ

Sanguinolentus, 'T'mm.

ベニマシコ

?enucleator, $I$.

ギンザンマシコ

japonicus, 1 ip.

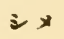

personitus, 'I' ، イカル (マメマワシ) 桑䉆

molannurus, Grm.

シマイカn 
Chaunoproctus, $B p$.

$$
\text { papa, Kittl. }
$$

\section{小篮原島}

Loxia, $L$.

albiventris, Swinh.

立山東京近傍黢河窑士山日光山東京筑前

$$
\text { 1スカ 交啄 }
$$

Pyrrhula, Briss.

千岛日光山立山束京筑前

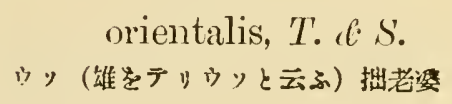

\section{ORDER RAP'SATORES. \\ Family Strigide.}

Nyctea, Steph.

美濃䗋屋村箱馆近傍

$$
\begin{aligned}
& \text { scandiaca, } L_{\text {, }} \\
& \text { シロフクロフ }
\end{aligned}
$$

Ninox, Hodlgs.

$$
\begin{aligned}
& \text { japonica, } T . \text { \& } S . \\
& \text { アキバッ゙ク }
\end{aligned}
$$

東京相模 下野京都 入重川岛薩摩

Syrnium, Sav.

maleuse rufescens, T.\&S.

東京 八丈島薩摩 筑前

$$
\text { フクロフ }
$$

Asio, Briss.

北海道 東京

$$
\begin{aligned}
& \text { accipitrimus, Pull. } \\
& コ ミ \text { ミッ゙ク }
\end{aligned}
$$

$$
\begin{aligned}
& \text { otus, } I . \\
& \text { トラフッ゙ッ }
\end{aligned}
$$

下野束京横㴼近傍 
Bubo, Dum。

blakistoni. Serbohm. シャフทロ

北海道

Scops, Sur.

japonicus, T. \& $S$.

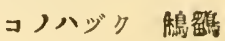

下野日光東京長崎 八文息

semitorques, T. r. SS.

オホコノハッ゙ク

東京長崎 沖繩息 烃本(信濃)

pryeri, Gurn.

沖繩岛

clegans, Cassin.

沖繩帛

\section{Family Accipitride.}

Supfamily Aquilina:

Aquila, Bur $:$

chrysactus. $I$.

下野日光松前加贺

イヌヌシ

Haliætus, Sur.

albicilla, $I$.

キジロロシ

長崎 北海道

pelagicus, Pall.

オホ】シ

上野 ウシ力八(北海道)

Pandion, Sar.

halixtus, $I$.

ミサゴ 鸮

上總笓野川能登宇出津長崎薩摩近江筑前 
Spizætus, $V$.

$$
\begin{gathered}
\text { orientalis, T. R.S. } \\
\text { クマタカ 解 }
\end{gathered}
$$

信浀木䉒伊勢北游道周防加贺

$$
\text { Subfamily. Mhinin. }
$$

Milvus, $C$.

$$
\begin{aligned}
& \text { melanotis, 'T. . } \\
& \text { トビ }
\end{aligned}
$$

東宗淡路 北敏道日记山周防日杵(罢後)

\section{Subfamily Buteoninx.}

Archibuteo, Brchm.

$$
\begin{aligned}
& \text { lagopus, } G m, \\
& \text { キッシノスリ }
\end{aligned}
$$

北海道

Buteo, Cuv.

japonicus, T. re $S$.

另, 天リ

後志睃河松本立山長崎干岛

hemilasius, T. \& $S$. オホノスリ

Bastastur, Hodys.

indicus, Gm.

サシバ

大和舅士山長崎周防 加賀

Pernis, Cuv. ,

apivorus, $L$.

日光山 北海道 爪王子

ヘேク

Subfamily $\Lambda$ ceipitrints.

Astur, Lacép.

東京信鹃 日光山北游道

palumbarius, $L$. むホタカ萻倍 
Accipiter, $B r$.

nisus, $L$.

雄をコノり倠名ハイタカと云

束京下野日光越㣭北游选松本加贺 gularis, T. \& $S$.

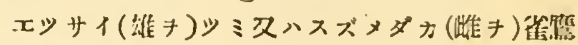

下野日光北海道敦贺烃本長崎加贺

Cer'chneis, Boie.

東京長崎 常陸 箱根川

$$
\begin{aligned}
& \text { timmmenlus, } L . \\
& \text { マク゚ソダカ(チヤッゲンボウ) }
\end{aligned}
$$

Surfamily Falconine.

Hypotriorchis, Boie.

北海道加贺 日光山

$$
\begin{gathered}
\text { subbuteo, } L \text {. } \\
\text { チゴハヤブサ }
\end{gathered}
$$

$$
\begin{aligned}
& \text { rsalon, } L \text {. } \\
& \text { コチウゲンポウ }
\end{aligned}
$$

東宗北海道

Falco, $M(e h)$.

peregrinns, Wils. ハヤブサ 愋

神系川近浐八文帛東京北海道八重山白加贺周防

\section{Subfamity Cincina.}

Circus, Lacép $p$.

下野上䊝東京北旅道

$$
\begin{gathered}
\text { cyaneus, } L \text {. } \\
\text { ハイ、ロチウ }
\end{gathered}
$$

spilonotus, Kaup.

青箖箱箱千帛

東京近傍長峻箱舒 œruginosus, $L$. チウヒ 


\section{CLASS MAMMALIA.}

\section{ORDER SIRENIA.}

Family Manatide.

Halicore, Illiger.

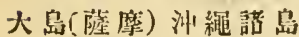

$$
\begin{aligned}
& \text { dugolyg, Illiger. } \\
& \text { ザンノイ (洲繩方言) }
\end{aligned}
$$

ORDER CEIACEA.

Family Balcenide.

Balæna, $L$.

?japonica, Gray.

セミクヂラ

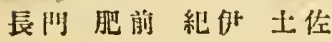

? Rhachianectes, Cope.

? glaucus, Copre. コクヂテ

五島細诂

Family Balanapteride.

? Megaptera, Gray.

? boops, Escter.

肥前長問級湖士估 ザトゥクヂラ

Balænoptera, Lacép.

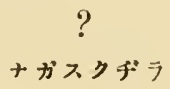

艮間肥前紀伊土估

? arctica, Schley.

肥前土佳 紀伊 


\section{SUIBORDER ODONTOCETI. \\ Family Physeteride. \\ Subbamily Physeterine.}

Physeter, $I$.

$$
\begin{aligned}
& \text { macrocephalus, } L \text {. } \\
& \text { マッコウクヂラ }
\end{aligned}
$$

肥前 紀什

\section{Subfamla Zirhune.}

? Hyperoodon, linfin.

要嗓

? rostratus, Chemnitz.

ッチクヂ

Family Delplinide.

Phocæna, Cuv.

? communis, Less.

北游洋

Neomeris, Gury.

phocienoides, Gray. スナメリ(ナメノウキ)

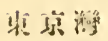

Globicephalus, l.cs:on.

sicboldii, Gray.

ゴトウクヂラ

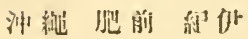

Grampus, Gray.

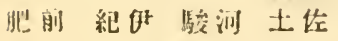

salkamata, Crray.

サカマタ 
Delphinus, $L$.

相模 安房 駿河

longirostris, Gray.

イルカ 海豚魚

\section{ORDER INSEGTIVORA. \\ SUBORDER INSECTIVORA VERA.}

Framily Soricide.

Croccidura, Wayler:

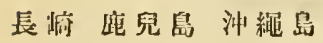

carulescens, Schaw. シャカウふッ゙、 香鼠

Sorex, $L$.

platycephalus, Temm.

カヘ子ッ゙ミ 水鼠

加賀 相模 武跐

dsinezumi, Temm.

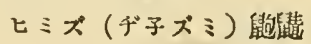

東京相榄下總下野北敏道

\section{Fumily Talpiclue. \\ Subfamley Myogaline.}

Urotrichus, Temm.

火和 紦伷相模信濃

$$
\begin{aligned}
& \text { talpoides, Temm. } \\
& \text { ヤャモ゙゙ラ }
\end{aligned}
$$

\section{SUbeamily Talfind.}

Talpa, $L$.

europæa, $L$. 
Mogera, Pomel.

相模駿河爬前

$$
\begin{aligned}
& \text { wogrura, Temm. } \\
& \text { モグラ 鼠鼠 }
\end{aligned}
$$

ORDER CHIROP'TERA.

SUBORDER MEGACHIROPTERA.

Family Pteropodidu.

Pteropus, Brisson.

dasymallus, Temm.

ヤクカハホリ

屋久,岀 (F. J.)

pselaphon, Suy.

キガサハラカハホリ

小篮原㤩

keraudrenii, Peters. var. loochooenis, Gray. チキナハカハホリ

沖繩諳岳

\section{SUBORDER MICROCHIROPTERA.}

Family Vespertilionida.

Plecotus, Gcoffroy.

下野北游遥

$$
\begin{aligned}
& \text { acitus, } L \text {. } \\
& \text { ウサギカハホง }
\end{aligned}
$$

Synotus, Kcys. \& Islas.

darjelingensis, Hodlyson. de Horsef. チ、・゙かホり

武政秩父郡

Vesperugo, Keys. \& $\mathrm{Bls}$.

pipistrellus, Sitrel. 
武藏秩父郡

noctula, Sclureb.

カ亦り

noctula. Schel). var. lasiopterus, Schrel.

ヤマカハホり

做豆柬亲

abramus, Temm.

アブラムシ

東宗長崎山口

Vespertilio, $L$.

capaccinii, Bonap.

モモジロカハホリ

越前唐人坊武藏秩父郡

akakomuli, Temm.

長崎近傍

Harpiocephalus, Gray.

箱根山

hilgeudorfi, Peters. テングカハホリ

Miniopterus, Bonap.

schreibersii, Natt. マビナガカハホリ

武藏秩父郡

Family Phinolophide.

Rhinolophus, Geoffroy.

minor Horsficld.

コキクがシ

唇崎近傍武藏武甲川相模小田原

ferrum-equinum, Leach.

キクガシラ

東京大和相模山城駿河歪走北海道 
ORIER RODENTIA.

\section{SUBORDER RODENTIA SIMPLICIDENTATA.}

Section Sciuromorfia.

Fumily Scimide.

Subfamily Sciurina.

Pteromys, Cuv.

leneogenys. Temm.

キカッギ 能丝

武藏大和下野

momonga, Temm.

モュンガ(ノプスマ)

机模信涨下野北海道

Sciurus, $I$.

lis, Temm.

リス(キ子ッ゙ミ)栗鼠

淡路 東京北海道

Tamias, Hlliger.

asiaticus, Allen.

トラフ子ッ゙ミ(五道胃兒)

北海道

Section Myoniorpha.

Family Myoxide.

Myoxus, Schreb.

萏士山 日光川

elegans, T'emm.

४子

Fumily Muride.

Mus, $L$.

rattus, $I$.

クマアッ゙ミ

東京 
東京

decumanus, $I$.

$$
\text { 子ッ゙ミ }
$$

minutus, Pall.

カヤ子ッ゙ ミ

東京

tanezumi, Temm.

ハタケタッ゙

speciosus, Temm.

ハッカ子ッ゙ミ 鼪鼠

東京

argenteus, Temm.

ヤマアッ゙ミ

下總伊豆

mollosinus, Temm.

アカ子ッ゙ミ

\section{SUBORDER RODENTIA DUPLICIDENTATA.}

SeCtion Thogomorpha.

Family Teporide.

Lepus, $L$.

brachyurus. Temm.

淡下路下野周防肥啳豊後

ノウサギ 鬼

variabilis, Pall.

清水䟥越後仙堂北海道加賀? エチゴウサギ（シロウサギ）

ORDER UNGUIATA.

Ungulata Vera. SUBORDER PERISSODACTYLA.

Family Equida.

Equus, L.

caballius, $L$.

ウマ 馬 


\section{SUBORDER ARTIODACTYLA.}

Framily, Suider.

Sus, $l_{\text {. }}$

lencomystax. Temm.

淡路豊後伊豆相模武藏周防脣阴

井ノシシ 野塔

沖繨岛

Family Cervide.

Cervus, $L$.

sika, Temm.

济鹿

淡路武藏周防陸前金落山北游道信浱長門豊後

Fumily Bovide.

Bos, L.

Nemorhaedus, Smilh.

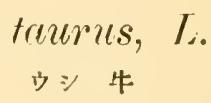

crispa. T'mm.

カモシカ

土花 日向武藏下野信濃飛驒加賀大和

ORDER ('ARNIVORA.

\section{SUBORDER FISSIPEDIA.}

Section Akluroidea.

Family Felider.

Felis, $l$.

影馬

domestica, Briss.

尒コ猫

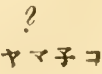


Section Cynoidea.

Family Canide.

Canis, $L$.

下野陸中

hodophylax, T'emm. ヤマイ邓射

familiaris (Japonica), Temm.

1又狗

familiaris(Yessoana).

× ע゙ 1 ×

procyonoides, Gray. タヌキ 狸

沖梫請島小笠原島旦南諸島 $フ$ 除キ棲急セザル地ナシ

japonicus, Gray.

キ甲尒狐

四國淡路沖繩諸曷對馬等キ除き棲息七サル地+シ

lagopus, $T_{\text {. }}$.

ウハップ島以北

alpinus, Paill.

北海道

$$
\text { Section Arctoidea. }
$$

Subfamily Lutrine.

Lutra, Erxl.

美漂淡路北海道武藏

vulgaris, Erxl.

カハキン 水制

Enhydra, Fleming.

lutris, $L$.

千島近海

ラッ 


\section{Subfamiay Mrilina.}

Meles, Storr.

武藏秩父郡

anakuma, Temm.

ア+クマ 貛

Subfamily Mustelina.

Mustela, $L$.

武藏秩父郡下野周防北海道

melampus, Temm.

テン 黄叟

brachyura, Gra!!.

北海道

エリ゙テン

Putorius, Cuv。

淡路東景鄧馬

itatsi, Pallas.

1タ千

? erminea. $I$.

北海道

エуイタチ

Family Trsider.

Ursus, $T$.

arctos, $L$. var. coralis,

北游道

ヤカク゚

japomicus, 'T'emm. ク 熊

信濃 日向越中越後加賀武藏

千曷宗谷 maritinus, Desm. シグマ 繁

\section{SUBORDER PINNIPEDIA.}

Family Otariide.

Otaria, Péron.

stelleri, Less.

上繌相模神津岛阿波淡路筑前北海道出零 
イプ近海千岛近湤

$$
\begin{aligned}
& \text { usina. } I . \\
& \text { フット七1 }
\end{aligned}
$$

Family 'Trichechide.

Trichechus, $L$.

籍舘 根空

$$
\begin{aligned}
& \text { rosmelus, L. } \\
& \text { 七イゥチ }
\end{aligned}
$$

$$
\text { Family Phocide. }
$$

Phoca, L.

北海道 A. . 新

foeticla, Fabr.

アザラシ

larbata, O. Fabr.

北游道

根空近海 equestris, Pall.

$$
\text { nキ }
$$

\section{ORDER PRIMATES. SUBORDER ANTHROPOIDEA.}

Family Cercopithecide.

Macacus, Cuv. d'Geoffi.

比海道沖繩島諸岛對等等キ除キ栖息七サルノ地ナシ

speciosus, F. Cuv. サル 榬

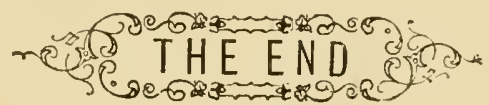


细11+1

? Arvicola

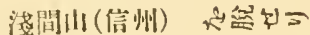


明 同

治

二 $\bar{t}$

四四

年 年

七 $t$

月 月

十 世

五 三

著發 印發

大

日

作 行 刷

賣

印出

者者者兌

捌

刷 版

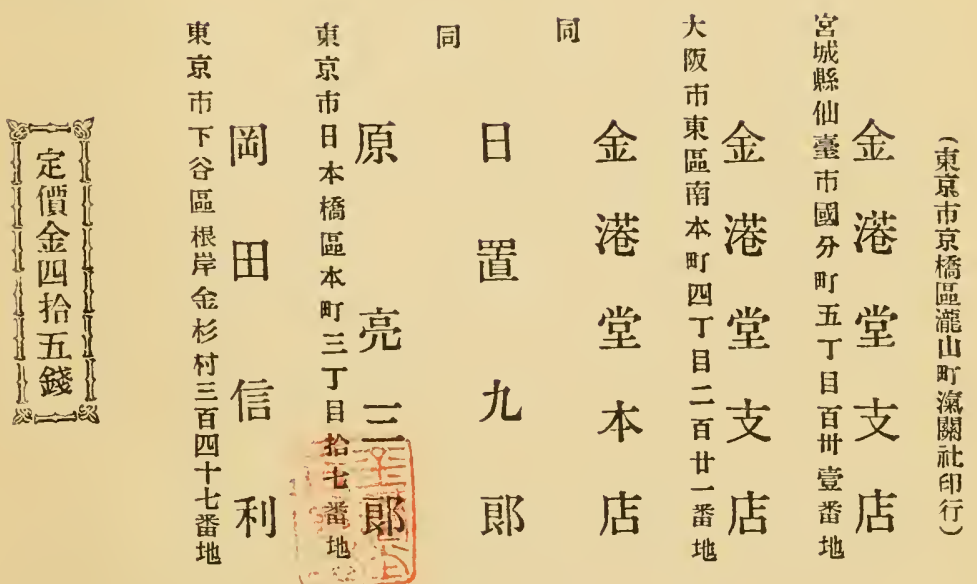




QL Okada, S.

606.56 Catalogue of J3 039 vertebrated animals of Rept. Japan. 
SMITHSONIAN INSTITUTION LIBRARIES 